\title{
INSTITUTIONAL SETTINGS AND URBAN SPRAWL: EVIDENCE FROM EUROPE*
}

\author{
Maximilian V. Ehrlich \\ University of Bern, \\ Center for Regional Economic Development \& CESifo
}

\author{
Christian A. L. Hilber \\ London School of Economics, \\ Centre for Economic Performance, Spatial Economics Research Centre \& \\ Center for Regional Economic Development
}

\section{Olivier Schöni}

University of Bern \&

Center for Regional Economic Development

\author{
First submission: 31 January 2017 \\ First revision: 14 October 2017 \\ Second revision: 8 December 2017 \\ Accepted: 10 December 2017
}

\begin{abstract}
*We wish to thank Hansjörg Blöchliger for insightful comments and suggestions. This research was made possible in part by a grant from the Swiss National Science Foundation (SNF project 162589 entitled "Urban Sprawl: The Role of Land Use Regulation and Fiscal Competition"). Support is gratefully acknowledged. Section 2 of this paper builds on a literature review conducted for the OECD. An extended version of the literature review is available as an OECD Working Paper (No. 1375). All errors are the sole responsibility of the authors. Address correspondence to: Christian Hilber, London School of Economics, Department of Geography and Environment, Houghton Street, London WC2A 2AE, United Kingdom. Phone: +44-20-7107-5016. E-mail: c.hilber@1se.ac.uk.
\end{abstract}




\title{
INSTITUTIONAL SETTINGS AND URBAN SPRAWL: EVIDENCE FROM EUROPE*
}

\begin{abstract}
This article explores the role of institutional settings in determining spatial variation in urban sprawl across Europe. We first synthesize the emerging literature that links land use policies and local fiscal incentives to urban sprawl. Next, we compile a panel dataset on various measures of urban sprawl for European countries using high-resolution satellite images. We document substantial variation in urban sprawl across countries. This variation remains roughly stable over the period of our analysis (1990-2012). Urban sprawl is particularly pronounced in emerging Central and Eastern Europe but is comparatively low in Northern European countries. Urban sprawl - especially outside functional urban areas - is strongly negatively associated with real house price growth, suggesting a trade-off between urban containment and housing affordability. Our main novel empirical findings are that decentralization and local political fragmentation are significantly positively associated with urban sprawl. Decentralized countries have a 25 to 30 percent higher sprawl index than centralized ones. This finding is consistent with the proposition that in decentralized countries fiscal incentives at local level may provide strong incentives to permit residential development at the outskirts of existing developments.
\end{abstract}

JEL classification: R3, R4, R5, H2, H3, H4, H7.

Keywords: Decentralization, housing supply, supply constraints, land use regulation, urban sprawl, Europe. 


\section{Introduction}

Urban sprawl - the spatial dispersion of settlements - is a major policy concern in many European countries. Yet little is known about how urban sprawl varies across countries and how it has evolved over time. Even less is known about the determinants of the spatial variation in urban sprawl across Europe and, in particular, about the potential role of countryspecific institutional settings in determining sprawl outcomes. The aim of this article is to start to fill these gaps in our knowledge and to identify areas for fertile future research.

Sprawl is an emotionally loaded, vague and contested concept that means different things to different people. It typically has a negative connotation among policy makers and the wider public. However, from a welfare economics point of view, it is not obvious whether the observed level of land use dispersion deviates from the optimum. Sprawl may be the consequence of market failure or policy failure, in which case reducing sprawl could be welfare improving. However, it may also simply be a reflection of the income elasticity of demand for space being satisfied rather than frustrated. In this paper, we refrain from a normative analysis of sprawl. Instead, our focus is on quantifying sprawl and identifying its determinants.

Point of departure is the fact that we can only analyze sprawl if we are prepared to define it in a way that actually allows us to measure it. In this article, we use land cover data derived from high-resolution satellite imagery to compute an index of the spatial dispersion of residential settlements. We provide details on how we compute this index in Section 3.2.

Europe is an excellent laboratory to study the phenomenon of urban sprawl for at least two reasons. First, high-resolution satellite imagery is available consistently for all European countries and for several time periods spread over more than two decades (1990, 2000, 2006 and 2012). We compile this data for 36 European countries to derive various measures of settlement dispersion and provide some stylized facts on the spatial distribution of sprawl and its evolution over time.

Second, European countries differ enormously not only in their economic conditions but also, crucially, in their institutional settings. This provides useful spatial variation that we can exploit in our empirical analysis, allowing us to shed some light on the impact of institutional settings that may influence land use and tax policies and, ultimately, sprawl outcomes.

The contribution of this article is fourfold. First, we provide a synthesis of the emerging literature that links land use policies and local fiscal incentives to urban sprawl. A main lesson of this literature, we would suggest, is that these factors, themselves ultimately determined by a country's institutional settings, may be crucial factors explaining urban sprawl.

Second, we provide several stylized facts on urban sprawl in Europe. We document significant spatial variation in its extent across countries. It is particularly pronounced in emerging Central and Eastern Europe. It is comparably low in Northern European countries and in the United Kingdom. Despite the remarkable differences in urban sprawl between countries, interestingly, within each country it has remained roughly stable over time, hinting 
at the importance of - effectively time-invariant - differences in country-specific institutional settings.

Third, we provide stylized facts on the potential trade-off between urban containment and housing affordability. Our country specific measures of sprawl are strongly negatively associated with country-specific real house price growth and the ratio of house prices to incomes. Countries that allow residential development outside functional urban areas have particularly low house price growth. Countries with strict containment policies - most notably the United Kingdom, which introduced very extensive green belts surrounding larger cities during the early $1950 \mathrm{~s}$ - are today confronted with serious housing affordability crises. ${ }^{1}$

Fourth, we explore the determinants of urban sprawl across European countries and document that conditional on country-specific economic factors (as measured through GDP per capita and a dummy for formerly communist Central and Eastern European 'catch up' economies), institutional settings (degree of decentralization and local political fragmentation) are crucial drivers of urban sprawl. While our sample size is rather small, and our findings thus need to be interpreted with some caution, simple regression analysis implies that decentralized countries have a 25 to 30 percent higher sprawl index than centralized ones. Moreover, greater political fragmentation is associated with increased urban sprawl. To our knowledge, our study provides the first evidence persuasively linking country-specific institutional settings - in particular the degree of decentralization - to urban sprawl. Our findings are consistent with the proposition that centralized systems often lack sufficient fiscal incentives for local governments to allow residential development thereby making housing supply price inelastic and, ultimately, causing housing shortages and price increases.

Our article is structured as follows. Section 2 provides a synthesis of the emerging literature on the regulatory and fiscal determinants of urban sprawl with a focus on the potential role of decentralization. In Section 3, we describe and document the data and our approach to measuring urban sprawl. Section 4 presents stylized facts on its spatial and intertemporal variation across European countries, stylized facts on the link between urban sprawl and housing affordability, and our main result that various measures capturing the institutional setting of a country affect urban sprawl. The final section concludes with an interpretation of our main findings and an agenda for future research to establish more firmly the causal links between national institutional settings, land use and tax policies, and urban sprawl.

\section{Background and Relevant Literature}

\subsection{Land use planning in decentralized settings}

The literature points out two main reasons why urban sprawl is likely to be more pronounced in decentralized settings. First, as argued by Glaeser and Kahn (2004), a system of local governments in which each government takes autonomous decisions with regard to land supply and land use may increase sprawl. Land developers and households can easily avoid

\footnotetext{
${ }^{1}$ Land use policies other than urban containment may also contribute to housing affordability problems. For example, height restrictions, preservation policies or lack of fiscal incentives to permit development capitalize demand shocks into higher prices.
} 
growth restrictions in a given jurisdiction by simply moving to another one, creating a pattern defined as 'leapfrogging'. Although sound from a theoretical point of view, empirical evidence on this mechanism is ambiguous. Glaeser and Kahn (2004) find that suburbanization only weakly correlates with the number of jurisdictions in a given area, thus arguing that jurisdictional sorting is likely not the main force driving sprawl.

Second, while local residents might have first-hand knowledge of local market failures - such as incorrect pricing of incompatible land uses and the social value of open land preservation and local authorities might implement land use policies to correct them, recent empirical research (Cheshire and Sheppard, 2002; Glaeser et al., 2005; Cheshire and Hilber, 2008; Hilber and Robert-Nicoud, 2013; Turner et al., 2014; and Gyourko and Molloy, 2015, for an overview) strongly rejects this idea in favor of the hypothesis that self-interest guides land use policy. The literature identifies fiscal zoning as one of the main instruments to pursue this self-interest. Fiscal zoning describes the process by which local residents (and homeowners in particular) get land use policies enacted in an attempt to create exclusive clubs in which only individuals with similar incomes and social backgrounds will live. The use of 'minimum lot size controls, discussed below, as an instrument to reduce the proportion of poor in a jurisdiction itself is a significant cause of lower density urban development. How does fiscal zoning relate to development patterns? Empirical evidence suggests that more extensive regulation hinders new development and decreases the responsiveness - or supply price elasticity - of local housing markets (see Mayer and Somerville, 2000; Quigley and Raphael, 2005; Glaeser and Ward, 2009; Dempsey and Plantinga, 2013; Hilber and Vermeulen, 2016).

As mentioned above, in decentralized settings, developers can easily circumvent the policies of a local government by moving into a nearby, less restricted jurisdiction. In more centralized settings, in which land use policies are coordinated or even applied homogenously throughout the country or a metropolitan area, such behavior is much less likely. In this line, Cunningham (2007) finds that by imposing an urban growth boundary around the greater Seattle area, development in rural areas declined, whereas in urban areas it increased. This is not surprising, as implementing land use regulation at the regional rather than local level leaves households with no other choice but to comply or move away from the region altogether. Interestingly, Brueckner and Sridhar (2012) illustrate what happens when land use regulation is implemented locally. In particular, they show that by imposing height restrictions - by setting maximum Floor to Area Ratios (FARs) - on Indian cities, their spatial size has increased to accommodate the increasing population. Additionally, building heights in non-restricted areas are higher than they would have been in the absence of any restriction. In a similar vein, Geshkov and De Salvo (2012) analyze the impact of different land use regulation policies on US urbanized areas and find, among other things, that minimum lot size requirements and maximum FARs increase their spatial extent.

Fiscal zoning relates to the literature sparked by Tiebout's (1956) seminal contribution on "voting with the feet". Over the past century, individuals have become both wealthier and more mobile. They have started to bid in land markets located at the outskirts of major urbanized areas, arguably choosing to live in places offering the preferred combination of land consumption and fiscal packages. In this respect, fiscal zoning is much more likely to happen in more decentralized settings, where local governments enjoy some fiscal autonomy 
and have the power to shape land use regulations. As such, the literature analyzing the role of fiscal decentralization for inter-jurisdictional competition (e.g. Besley and Case, 1995) can also be applied to decentralization of land use policy and its interaction with the local tax system.

Another strand of the literature argues that stricter land use regulation in the form of minimum lot size restrictions and open land preservation may spur sprawl even within the local area where they are implemented (see Fischel, 2000). Moss (1977) and Pasha (1996) provide two alternative theoretical frameworks that help understand the conditions under which this may occur. Irwin and Bockstael (2004) argue that land use regulations produce not only a direct effect via increasing development costs of undeveloped land, but also create a land use externality on adjacent parcels. In particular, they suggest that land use regulations that preserve open space create a positive amenity effect on nearby developable land. Looking at development patterns in Calvert County, Maryland, they find that parcels surrounded by preserved land have higher development rates, whereas parcels near industrial development showed lower development rates. They conclude that land use controls that preserve open land may have the effect of i) draining development from central high-density areas, and ii) attracting new development towards areas that have protected open space. As a consequence, such policies may contribute to leapfrogging and sprawling development. McConnell et al. (2006) also consider land use patterns in Calvert County, and find that those surrounding an individual parcel affect its development intensity and that zoning regulation in the form of minimum lot size restrictions encourage low-density sprawling residential development.

\subsection{The interaction between fiscal and land use instruments}

In more decentralized settings local governments finance public services mainly by levying local taxes, allowing them to set fiscal incentives to attract new residents and expand the tax base. Because local jurisdictions can autonomously decide which fiscal instruments to use and to what extent - and households react to these incentives - land use varies across jurisdictions. Such heterogeneity in land use patterns is less likely in more centralized settings, since taxes are levied centrally and redistributed to local governments in the form of transfers. In this case, unless fiscal redistribution favors specific places that allocate more land for development, the fiscal system does not add variation to land use patterns, as there are no positive fiscal incentives at the local level. ${ }^{2}$

A wide range of the empirical literature shows that households and firms react to local fiscal incentives. Households choose to locate in jurisdictions that they deem offer the largest net fiscal benefit, i.e. the best tax-public services relation. Considering multistate metropolitan areas, Coomes and Hoyt (2008) document that location decisions of households are indeed influenced by tax rate differentials and differences in public spending. Similarly, Rohlin et al. (2014) find that firms sort across state boundaries to avoid adverse tax effects.

Fiscal instruments may also affect the composition, mostly residential versus commercial, of new development. Solid evidence is limited to a handful of studies. Quigley and Raphael

\footnotetext{
${ }^{2}$ Of course, variation in land use patterns is still possible in more centralized settings, as local jurisdictions differ e.g. in their amenities or their proximity to major urban centers.
} 
(2005) point out how California's tax policies create fiscal disincentives to build new, midpriced housing in favor of expensive housing and retail buildings. In fact, jurisdictions in California can benefit from sales tax revenues, whereas property taxes are limited to $1 \%$ of the last transaction price. Cheshire and Hilber (2008) investigate the effects of the Uniform Business Rate adopted in the United Kingdom in 1990, documenting that fiscal centralization implied a significant disincentive for local authorities to allow new commercial development, making the supply of office space more inelastic and capitalizing demand for such space into higher market prices. Although Cheshire and Hilber did not explore this, a corollary of their main finding is that by making development of commercial real estate comparably less attractive, local authorities might have been comparably more willing to allocate scarce local sites for residential purposes. Burnes et al. (2012) document that those jurisdictions in Florida that have higher sales tax rates prefer to attract large shopping malls over manufacturing firms. Jacob and McMillen (2015) find that higher sales tax rates give jurisdictions an incentive to attract commercial and industrial firms. Finally, focusing on German municipalities, Buettner (2016) provides a theoretical approach investigating the trade-off between increasing the land available for commercial use - the main source of revenue of German municipalities is a business tax - and quality of life in the jurisdiction. He argues that making too much land available for commercial development may actually hurt mobile households.

If local governments have fiscal incentives to attract new residents and businesses, they are likely to compete with each other to attract them. The strategic behavior of jurisdictions is likely multidimensional and not limited to fiscal instruments, as often assumed. Theoretical models show that the uncooperative equilibrium may not only be characterized by inefficiently low taxes on mobile factors but also by an overprovision of public inputs that benefit the mobile factor (Bucovetsky, 2005; Fenge et al., 2009). Hauptmeier et al. (2012) suggest that local governments do in fact use both tax rates and public inputs to compete for mobile tax bases. Given this evidence, it seems reasonable to assume that land use regulation as well may be implemented strategically. Brueckner (1995) and Helsley and Strange (1995) are among the first to analyze such interactions. They point out how local land use regulations - in the form of growth control policies - may be strongly intertwined: the adoption of a growth control policy restricting the supply of new land for development in a given jurisdiction creates spillovers that influence land use policies of nearby jurisdictions. Brueckner (1998) provides empirical evidence by investigating strategic interactions of growth-control restrictions implemented by Californian cities. In line with the results obtained for property tax competition, local jurisdictions seem to mimic the growth control policies of nearby jurisdictions. Put differently, a given jurisdiction is likely to adopt stringent growth control restrictions when nearby jurisdictions implement tight growth controls as well. Brueckner's (1998) theoretical framework suggests that this interdependency arises because growth control policies in a given municipality depend on the regional housing market supply-responsiveness, which results from growth control policies in other jurisdictions.

Thus, competitive behavior of local governments in taxes and land use regulation is likely to have important consequences for land use patterns. Competition between local governments is likely to be most intense in highly decentralized countries, where local governments have 
considerable control over both land use and tax policies and benefit from attracting specific groups of residents and businesses. In all cases, the ways in which local governments compete depends on the incentives that they face and the instruments that they control.

Heyndels and Vuchelen (1998) investigate the potential strategic interactions among Belgian municipalities in setting property taxes. They find that local jurisdictions do indeed mimic tax rates of neighboring municipalities, but this interdependency decreases with geographical distance. Brueckner and Saavedra (2001) do a similar analysis for 70 cities of the Boston metropolitan area. Consistent with Heyndels and Vuchelen (1998), they also find an upwardsloping reaction function.

Because the competition between local governments is likely multidimensional, local governments might affect land use patterns by interacting land use and fiscal policies (taxation and provision of public goods). From a theoretical perspective, the joint effect on land use patterns of strategically using the two instruments simultaneously is not obvious. Moss (1977) conceptualizes an interaction between minimum lot size restrictions and property taxes. In his model, minimum lot size requirements may increase the conversion rate of rural into urban land, thus increasing the size of an urban area. However, this conversion is slowed down when property taxes on developed land increase faster than those on agricultural property. Voith and Gyourko (2002) adopt a theoretical framework in which a public policy that subsidizes homeownership according to income, thereby favoring higher income households, may lead to greater income segregation when lot size restrictions are binding. Even in a setting where poor and rich households have the same preferences for city versus suburban living, there is residential sorting by income. This implies that the observed migration of richer households towards suburban areas - and the subsequent low-density development - could have occurred, in part, due to a combination of land use policies and fiscal incentives. A study by Basten et al. (2017) supports this conclusion as it documents that high-income households systematically sort into low-tax jurisdictions that tend to be low density places, where the provision of local public goods and services is more expensive.

\subsection{Capitalization mechanisms and land use patterns}

Recent research shows that binding housing supply constraints - such as tight land use regulation - and tax differentials may be responsible for misallocating households across space. In a widely quoted study, Hsieh and Moretti (2015) argue that housing supply constraints are responsible for misallocation of the labor force across the United States: as mobile workers were increasingly unable to live in more productive cities due to regulatory supply constraints, wage dispersion across 220 US metropolitan areas doubled from 1964 to 2009, lowering the output and welfare of the whole country. Similarly, Fajgelbaum et al. (2015) argue that US state taxes may be responsible for the spatial misallocation of individuals and firms, thus reducing workers' welfare. Capitalization effects may prevent mobile workers to move to larger, more productive agglomerations.

The empirical literature provides strong evidence in support of the hypothesis that local land use constraints are capitalized into house prices (for recent rigorous evidence see e.g. Saiz, 2010, for the US or Hilber and Vermeulen, 2016, for the United Kingdom). Fischel (1990) 
and Quigley and Rosenthal (2005) provide a literature review linking growth control with land and house prices. The main message is that tighter land use constraints tend to benefit owners of developed land and hurt owners of undeveloped land (see the early work of Engle et al., 1992, or more recently Hilber and Robert-Nicoud, 2013). Zoning restrictions reduce the amount of land available for development and thus increase its price. The price of developed land may also be higher because zoning restrictions create a positive amenity effect, thus increasing the willingness to pay of would-be residents. Finally, prices may increase if zoning restrictions attract wealthy households, thereby expanding the local tax base. In contrast, the price of undeveloped land falls, as new development becomes more difficult and expensive, thus decreasing demand from land developers.

Similarly, capitalization of local taxes into house prices largely depends on the willingness to pay of households for the public services obtained in return. If the local government underprovides a given public service, raising tax rates will increase the willingness to pay to live in the jurisdiction. This is because households benefit from higher public spending (assuming that local jurisdictions are not leviathans and do not waste money). In this case, capitalization of the tax increase into higher house prices can be expected. However, if the additional tax is used to fund a public service that is overprovided, households are not willing to pay more to live in the jurisdiction the local tax increase should be negatively capitalized into house prices. ${ }^{3}$

\section{Data}

\subsection{Data description}

To analyze the relationship between governmental decentralization and land use patterns, we gather data from several European agencies. Below we provide the main data sources as well as a brief description of the data. Summary statistics are provided in Table 1. The reader may want to refer to Appendix Table A1 for supplementary information on the data sources and to Table W1 in the Web Appendix for the full data set used in our core analysis. We provide maps of the spatial variation of key explanatory variables in the Web Appendix as well.

Land cover - The Corine Land Cover (CLC) inventory provides high-resolution satellite imagery data classifying land cover into 44 categories. The inventory includes four waves 1990, 2000, 2006, and 2012 - for a panel of European countries. There are data on 20 Western European countries - Austria, Belgium, Germany, Denmark, Finland, France, Greece, Ireland, Iceland, Italy, Liechtenstein, Luxemburg, Malta, Norway, Netherlands, Portugal, Spain, Sweden, Switzerland, and United Kingdom - and on 16 Central and Eastern European countries - Albania, Bosnia and Herzegovina, Bulgaria, Croatia, Czech Republic, Estonia, Hungary, Latvia, Lithuania, Macedonia, Montenegro, Poland, Romania, Slovakia, Slovenia, and Serbia. In Section 3.2, we illustrate how we use the CLC inventory to measure sprawl.

\footnotetext{
${ }^{3}$ See Hilber (2017) for an in depth discussion of the capitalization of local public goods and taxes into house prices, and the economic implications of such capitalization effects.
} 
Decentralization - Several decentralization measures have been suggested in the literature. Various measures based on a country's constitution are obtained from Treisman (2008). Our first measure is a variable that captures whether a country's constitution provides autonomy to subnational legislatures in certain specified areas or assigns residual powers to subnational governments, i.e. allows them to legislate on areas not explicitly assigned to other levels. We denote this dummy variable subnational autonomy in the tables. Second, we consider whether a country's constitution can be classified as federal according to Elazar (1995). This dummy variable is referred to as federal constitution. ${ }^{4}$ Third, still relying on data derived from Treisman (2008), we measure how many levels of government there are in a country. We refer to this variable as no. tiers. ${ }^{5}$ Lastly, we use the Regional Autonomy Index (RAI), proposed by Hooghe et al. (2016). This variable summarizes different dimensions of governmental decentralization into one single index. We refer to it as regional autonomy index. Specifically, the country-level RAI aggregates decentralization measures computed for sub-national tiers. There are 10 categorical measures entering the RAI index, with low values corresponding to heavily centralized institutional settings and high values to heavily decentralized ones. ${ }^{6}$ The RAI index is available for 81 countries from 1950 to 2010. According to the literature surveyed above, we expect that more decentralized countries are generally characterized by more dispersed residential development.

Institutional fragmentation - The degree of dispersion of residential development should also depend on the intensity of competition between subnational units. Conditional on the population size, the competition intensity can be expected to depend on the number of competitors. Eurostat publishes detailed information on low-tier (municipality-level) administrative boundaries for the whole of Europe. We use 2013 municipality boundaries to compute the number of municipalities in a country and label this variable in the tables as no. municipalities. Holding constant the country's population, we can interpret this variable as capturing the municipality density per country inhabitant. This density, which varies widely across countries ${ }^{7}$, proxies the degree of country-specific institutional fragmentation. Conditional on the degree of decentralization, we expect more fragmented countries to display more scattered land use patterns.

Functional urban areas - The OECD provides a harmonized definition of European functional urban areas based on commuting patterns. We use these functional urban areas to compute sprawl at a more disaggregated level. More precisely, for each country we compute

\footnotetext{
${ }^{4}$ See Web Appendix Figure W1 for a map with the federal status by country.

${ }^{5}$ Web Appendix Figure W2 illustrates the wide variation in this measure by country.

${ }^{6}$ These measures include the degree of autonomy of a regional government, the authority of a regional government to implement specific policies (such as economic, welfare, education, security, and immigration policies), the degree of a sub region's fiscal autonomy, borrowing autonomy, the extent to which a sub region can autonomously legislate and execute laws, the degree to which regional representatives can influence national legislation, the extent to which sub-regional governments impact national policies, the extent to which the national tax revenue distribution is affected by regional representatives, the degree to which a regional government influences subnational and national borrowing constraints, and the extent to which sub-national representatives affect constitutional changes. See the Web Appendix Figure W3 for a map illustrating the spatial variation in the RAI.

7 See the Web Appendix Figures W4 and W5 for an illustration of country-specific discontinuities in municipality size and for a map of resulting municipality densities by country.
} 
sprawl for country areas outside major functional urban areas, and within functional urban areas but outside city centers. This allows us to investigate whether development patterns significantly differ across countries depending on urban areas and commuting patterns.

House prices and other controls - We consider real house price indices published by Girouard et al. (2006). These indices are computed by adjusting nominal price indices based in 2010 with the private consumption deflator published by national statistical offices. This allows us to relate long-term price dynamics to development patterns. Additionally, we control for GDP per capita in the year 2000 (adjusted for PPP) to account for the disparity of economic activity across countries. Per-capita GDP and population data stem from the World Development Indicators.

\subsection{Measuring Urban Sprawl}

Sprawl is an elusive concept and a variety of measures has been used in the literature to try to capture it, depending on both theoretical and practical considerations. Wassmer (2000), Galster et al. (2001), and Song and Knaap (2004) offer an overview of alternative measures. ${ }^{8}$ Theoretical work tends to identify sprawl with population density gradients (Glaeser and Kahn, 2004; Song and Zenou, 2006) and the urban spatial extent (Brueckner and Sridhar, 2012). In line with theoretical work, early empirical analyses measured sprawl with population density and urban extent (Brueckner and Fansler, 1983). There is, however, a recent trend to rely on Geographical Information System (GIS) data to measure sprawl patterns more systematically. A major contribution was that of Burchfield et al. (2006), who rely on satellite images mapping the US surface in cells of 30x30 meters. Burchfield et al. (2006) define a sprawl index for US metropolitan areas by computing for each individual developed cell the share of undeveloped land surrounding that cell within a square kilometer, and then averaging across all developed cells in the urban area. The index corresponds to the share of open land surrounding an average developed cell within a square kilometer, thus providing insights on the spatial dispersion of development that may not be captured by a simple density measure.

In the present paper, we follow Burchfield et al.'s (2006) approach and employ $100 \times 100$ meter resolution raster data provided by the CLC. We group the 44 land cover categories into four main classes: residential developed, non-residential developed, developable, and undevelopable. The non-residential developed category includes, in particular, industrial and transportation surfaces. The developable class contains plots of land that are not developed but are potentially developable. Agricultural, woodland, and pasture areas belong - among others - to this class. The undevelopable class comprises parcels that are physically undevelopable or extremely costly to develop, such as lakes or glaciers. ${ }^{9}$

Using these four land cover classes, we compute a sprawl index $S p r_{c t}$ for each European country $c$ in a given year $t$ according to the following formula:

\footnotetext{
${ }^{8}$ A more complete discussion of alternative measures of sprawl and urban form is provided in Clifton et al. (2008).

${ }^{9}$ See Appendix Table A2 for a precise definition of these classes according to the CLC land cover categories.
} 
$S p r_{c t}=\frac{1}{\sum_{i \in c} 1\left(l_{t}(i)=r e s\right)} \sum_{i \in c} 1\left(l_{t}(i)=\right.$ res $) \frac{\sum_{j} 1\left(d_{i j} \leq 500 \cap l_{t}(j)=\text { free }\right)}{\sum_{j} 1\left(d_{i j} \leq 500 \cap\left(l_{t}(j)=\text { free } \mid l_{t}(j)=\text { res }\right)\right)}$,

where $d_{i j}$ denotes the "crow flight" distance between pixels $i$ and $j$, the function $l_{t}($.$) maps$ pixels to one of the four class values at time $t$, and 1(.) is an indicator function. The intuition behind formula (1) is the following: for each individual pixel, we compute the share of developable (free) land within a radius of 500 meters. This share is obtained by dividing the number of free pixels by the total number of free and residential pixels within the considered area. Next, we average the computed shares over all pixels classified as residential in a given country.

Two characteristics of our sprawl measure are worth noting. First, as in Burchfield et al. (2006), we average exclusively over residential pixels. This allows us to estimate the percentage of developable land surrounding an average residential plot of land. Second, developed and undevelopable land do not enter the share of 'free land' in Equation (1). We would justify this exclusion with the argument that scattered residential development should be considered as sprawling only in those areas where development is not (physically) constrained. For example, according to our definition a residential pixel of a coastal urban area will not be counted as 'sprawling' if it is located close to a body of water. This exclusion leads to sprawl values that are more conservative than those suggested in the literature, and in particular by Burchfield et al. (2006). Heterogeneous geography should be accounted for as it may potentially affect cross-country comparisons of urban sprawl. ${ }^{10}$

\section{Empirical Analysis}

\subsection{Urban Sprawl across Europe and over Time}

Figures 1 and 2 illustrate the cross-sectional variation in aggregate urban sprawl and sprawl outside functional urban areas. The countries with the highest levels of urban sprawl are the Czech Republic, Slovenia, Albania, Poland, and Slovakia while the United Kingdom, Iceland, the Netherlands, Norway and Denmark display the lowest degree of sprawl. Cross-country differences range from a sprawl level of 0.52 in the Czech Republic to less than half of this in the United Kingdom. Overall, sprawl turns out to be most pronounced in Eastern and Central Europe and least pronounced in Northern Europe. The cross-sectional variation is similar for sprawl outside functional urban areas, with one notable exception. Portugal is overall only the $12^{\text {th }}$ most sprawling country in Europe but it has the second highest sprawl level outside functional urban areas. Figure 3 (for Western European countries) and Figure 4 (for Central and Eastern European countries) depict the development of sprawl over time for the countries in our sample. It is evident that the levels of sprawl are rather stable over time. ${ }^{11}$

\footnotetext{
${ }^{10}$ An alternative approach would be not to exclude developed and undevelopable land and add (i) the share of undevelopable land and (ii) a proxy for topography as control variables in our regressions. This would allow us to identify and disentangle the effects of land cover types and topography on our measure of urban sprawl. We leave this for future work.

${ }^{11}$ This and the fact that we do not have detailed information on changes for the key explanatory variables prevent us from estimating first difference models. However, we note that a very simple analysis regressing the first difference of sprawl on a dummy variable for Central and Eastern Europe, conditional on log income, is mildly supportive of the hypothesis that sprawl has increased more in Central and Eastern Europe than in the rest
} 


\subsection{Urban Sprawl vs. Housing Affordability}

Many Central and Eastern European countries but also countries such as Portugal, Austria or Switzerland are characterized by residential development taking place on the outskirts rather than in central, high-density areas. Yet, not all European countries are sprawling. Urban development in countries such as the United Kingdom, Sweden, Norway or Iceland is largely 'contained'. The case of the United Kingdom is particularly interesting in that containment is the result of a highly restrictive planning system that for six decades has imposed, amongst other measures, very extensive 'green belts' surrounding larger cities. While green belts - in conjunction with a lack of fiscal incentives to permit development, height restrictions, view corridors and widespread preservation policies - largely ${ }^{12}$ successfully contain urban development, they create a different kind of problem. By limiting the long-run supply of housing, these policies contribute to a severe housing affordability crisis (Hilber and Vermeulen 2016). Sweden and Norway similarly observed strong increases in real house prices over the last two decades.

To investigate whether there is a common trade-off between containment and housing affordability, we collected data on real house price indices from the OECD and Knoll et al. (2017). Figure 5 shows the growth of real house prices - smoothed over a 12-year moving average (6 years on either side of the central year) to partial out the impact of cyclicality on price dynamics - between 2000 and $2015^{13}$ against the average sprawl between 1990 and 2012. It is evident that urban sprawl is significantly negatively correlated with the growth of real house prices. The data suggests a correlation coefficient of -0.42. Countries with a high average degree of urban sprawl such as Portugal, Spain or Austria experienced comparably low increases in real house prices, whereas the 'contained' United Kingdom, Sweden and Norway observed strong real house price increases during the same period.

In Figure 6, we excluded functional urban areas from the computation of the sprawl index in order to compare only areas with comparatively low density across countries. ${ }^{14}$ The negative association between sprawl and the average quarterly change in real house prices is even more pronounced, with a correlation coefficient of -0.61 .

While the real house price growth numbers in Figures 5 and 6 account for inflation differences across countries, the picture might be blurred by a more pronounced increase in real incomes in countries with low sprawl. Thus, to establish more confidence in our proposition that there is indeed a trade-off between containment and housing affordability, we further consider the change in the ratio between house prices and incomes. As illustrated in

of Europe. We find that the change in sprawl was about 0.01 units higher in Central and Eastern Europe with this effect being statistically significant at the 10 percent level.

${ }^{12}$ Green belts are not entirely successful in containing urban sprawl because in the most prosperous cities (London, Cambridge, Oxford), one can observe that urban development 'jumps' over green belts. In a similar vein, Cheshire et al. (2017) document that tight local land use restrictions cause an increase in the commuting distance.

${ }^{13}$ We choose the window of the moving average based on the average duration of country-specific housing cycles as found in Bracke (2013).

${ }^{14}$ For instance, in the Netherlands 18 percent of the total land is assigned to functional urban areas whereas functional urban areas make up only 1.2 percent of all land in Latvia. 
Figure 7 for aggregate urban sprawl and in Figure 8 for sprawl outside urban areas, a negative correlation is evident even for the change in the house price-to-income ratio plotted against the sprawl measures. These correlations are somewhat lower than the simple real house price growth ones and there may still be various confounding factors so we cannot read too much into these correlations. Yet, a trade-off between containment and housing affordability is consistent with theory as well as with the stylized facts presented in this paper.

In a next step, we empirically investigate underlying factors that determine urban sprawl and, in this context, we highlight the role of decentralization and political fragmentation.

\subsection{Determinants of Urban Sprawl in Europe}

Urban sprawl is likely affected by a country's state of economic and demographic development as well as by its institutional setup, which in turn determines both planning policies and fiscal incentives to permit development at the local level. In the following, we focus on the institutional setup while controlling for the state of economic and demographic development. In Table 2, we present the effects of four alternative measures of decentralization on urban sprawl. Our regression sample consists of 31 countries because we lack information on the decentralization measures for Lichtenstein, Montenegro and Serbia and information on the number of municipalities is missing for Albania, Bosnia-Herzegovina and again Montenegro. In each of the specifications, we control for the state of economic development by including the logarithm of per-capita GDP in the year 2000 (adjusted for purchasing power parity). We also include a dummy variable for Central and Eastern European (CEE) countries. This variable captures unobserved characteristics associated with these countries, possibly the unique institutional setting related to their common history as communist countries. The negative correlation between log per capita GDP and the CEE dummy variable is very strong at -0.76 , indicating that the CEE dummy may at least partially capture 'very low income' levels as well.

We run simple OLS regressions and keep the empirical model parsimonious due to the low number of observations. Three results stand out. First, CEE countries display a higher degree of urban sprawl. This may be due to urbanization being still less pronounced in these catching-up countries and thus policies aiming at urban containment receive less attention. Controlling for decentralization urban sprawl is between 12 and 18 percentage points higher in CEE countries compared to non-CEE countries. Controlling for the CEE status, log GDP per capita is positively associated with urban sprawl in four out of five specifications, but the effect is never statistically significant at conventional levels.

Second, decentralization is significantly positively correlated with urban sprawl, independent of the measure of decentralization we use. Countries where subnational legislatures have 'autonomy in certain areas or residual powers' have a level of sprawl that is 0.095 to 0.116 units higher. The average level of sprawl in countries without autonomous subnational jurisdictions is 0.39 such that countries characterized by subnational autonomy display a 25 to 30 percent higher level of sprawl. This is consistent with the literature - discussed in Section 2 - which suggests that regional competition and a lack of inter-regional coordination in decentralized settings spur urban sprawl. These results are robust to using alternative 
measures of decentralization. Countries classified as federal according to Elazar (1995) exhibit a level of urban sprawl that is about 7 percentage points higher. Urban sprawl is also strongly positively associated with the number of tiers of government, as a proxy for decentralization, as well as with the continuous index of regional autonomy introduced by Hooghe et al. (2016).

Third, we directly exploit variation in the degree of inter-regional competition across countries. In column 5 of Table 2, we account for the degree of institutional fragmentation in addition to the indicator about whether subnational units have some degree of autonomy. In particular, we estimate the effect of the number of municipalities that are potentially competing for new residents or a mobile tax base. As the absolute number of municipalities is strongly dependent on country size, we further control for country population. We find that the degree of sprawl increases significantly with the number of municipalities. This is consistent with the literature on jurisdictional competition in federations and adds further confidence in the hypothesis that the degree of decentralization is an important determinant of urban sprawl. Remarkably, our simple regressions explain up to 51 percent of cross-country variation in urban sprawl.

Table 3 follows the same structure as Table 2 but exploits variation in residential sprawl outside functional urban areas. Consistent with the results reported in Table 2, we find that decentralization matters. The effects of the individual proxies for decentralization remain qualitatively and quantitatively similar to the ones for aggregate sprawl. The only exception relates to the proxy for the degree of competition as measured by the municipality density, which ceases to be significant. However, the magnitude of the effect remains similar. ${ }^{15}$

Another potential explanatory variable of interest is the subnational competence and authority in spatial planning. Silva and Acheampong (2015) provide up-to-date information on land-use planning systems and policy instruments for all OECD countries, including the 24 European OECD countries in our sample (we lose data points for seven European countries that do not belong to the OECD). Estimating a regression with only 24 observations and a rather coarse measure of 'planning autonomy' is problematic. Leaving this caveat aside, we report results in Appendix Table A3. The effect of the planning autonomy variable on residential sprawl is positive across most specifications (as expected) but never close to statistically significant at conventional levels. Importantly, however, including the variable does not greatly affect the coefficient estimates of our measures for the degree of decentralization. These remain qualitatively and quantitatively remarkably similar compared to those reported in Table 2.

\section{Conclusions and Outlook}

This article explores patterns of urban sprawl and their determinants across Europe and aims to provide a road map for fertile future research. We show that urban sprawl is particularly prevalent in Central and Eastern Europe but also, to a lesser extent, in the Alpine and some of the Southern European countries. Interestingly, although urban sprawl patterns differ vastly across countries, at country level, they do not change substantially over a 20-year period, and

\footnotetext{
${ }^{15}$ Note also that an alternative specification, which includes the municipal density, instead of the number of municipalities and the population size separately, shows a significantly positive effect of municipal density.
} 
there is no clear European-wide time trend. This is suggestive that institutional settings - that vary substantially across countries but little within countries over time - may drive urban sprawl.

Our main empirical results indicate that institutional factors are important in determining urban sprawl, most likely via determining the restrictiveness of land use policies and fiscal incentives to develop at the local level. Holding economic conditions - as measured by per capita GDP - constant, decentralized European countries have a 25 to 30 percent higher level of sprawl compared to centralized ones. Moreover, countries with greater political fragmentation at local level - and presumably a greater degree of interjurisdictional competition and poorer coordination - also are more sprawling, other things held equal. To the best of our knowledge, this study is the first to provide direct evidence of a link between variables capturing the institutional setting and urban sprawl.

Of course, our analysis is limited in scope by its very nature. Our cross-sectional regression sample is confined to 31 countries. Future work may be able to conduct a more disaggregated analysis at the regional, sub-regional or even local level and perhaps exploit variation within country over time, controlling for area and time fixed effects. Additionally, our variables capturing the 'institutional setting' are coarse. Future work ought to try to understand better the underlying channels that create such a strong discrepancy in sprawl between decentralized and centralized countries. Such research may also explore the interaction effects of planning and tax policies and the various underlying instruments.

Measures of political and fiscal decentralization available to us are too coarse and the variation not sufficient to disentangle the two drivers separately. Moreover, few measures are available for all - or even most - countries in our sample. Careful future data collection efforts could help shed more light on the underlying channels that drive urban sprawl in Europe and elsewhere.

Our findings can only be suggestive of causation. Whilst it seems highly plausible to argue that the degree of decentralization and political fragmentation themselves are not driven by sprawl (reverse causation), spurious correlation is a potential problem. That is, factors that happen to be correlated with measures of decentralization or political fragmentation might be driving urban sprawl. We are not aware of omitted variables that (i) are correlated with the degree of decentralization or political fragmentation but are not driven by these institutional variables, and, (ii) have their own independent effect on urban sprawl. However, we are wary of the possibility.

Lastly, our analysis suggests that containment policies - such as those implemented in the United Kingdom - are not a 'free lunch'. All countries in our sample - that are at the bottom end of the sprawl distribution with the notable exceptions of the Netherlands and to a lesser extent Denmark - have observed strong growth in real house prices and a deterioration of housing affordability as measured by an increase in the house price-to-income ratio between 2000 and 2015. These findings point to a trade-off between containment and housing affordability. However, we stress that we do not believe reducing sprawl necessarily implies housing affordability crises. Land use regulations serve an important purpose - to correct market failures (such as externalities or the provision of local public goods). In theory, it is 
possible to devise policies or 'solutions' that correct market failures without leading to excessive sprawl or driving up housing costs massively (see e.g. Cheshire and Sheppard 2005; Cheshire 2009, 2013). However, in practice, political economy forces make achieving welfare-maximizing solutions hard (Fischel 2000; Hilber and Robert-Nicoud 2013). Future research could focus on these political-economy forces. Better understanding these, might allow well-intended policy makers to design institutional settings (at constitutional level) that optimize social welfare via minimizing the powers of vested interests. 


\section{References}

Basten, C., Ehrlich v.M., and Lassmann, A. 2017. Income Taxes, Sorting, and the Costs of Housing: Evidence from Municipal Boundaries in Switzerland. Economic Journal. 127(601): 653-687.

Besley, T., and Case, A. 1995. Incumbent Behavior: Vote-Seeking, Tax-Setting, and Yardstick Competition. American Economic Review. 85(1): 25-45.

Bracke, P. 2013. How long do housing cycles last? A duration analysis for 19 OECD countries. Journal of Housing Economics. 22(3): 213-230.

Brueckner, J.K. 1995. Strategic Control of Growth in a System of Cities. Journal of Public Economics. 57(3): 393-416.

Brueckner, J.K. 1998. Testing for Strategic Interaction among Local Governments: The Case of Growth Controls. Journal of Urban Economics. 44(3): 438-467.

Brueckner, J. and Fansler, D. 1983. The Economics of Urban Sprawl: Theory and Evidence on the Spatial Sizes of Cities. Review of Economics and Statistics. 65(3): 479-482.

Brueckner, J.K. and Saavedra, L. 2001. Do Local Governments Engage in Strategic Property Tax Competition? National Tax Journal. 54(2): 203-229.

Brueckner, J.K. and Sridhar, K.S. 2012. Measuring Welfare Gains from Relaxation of Land Use Restrictions: The Case of India's Building-height Limits. Regional Science and Urban Economics. 42(6): 1061-1067.

Bucovetsky, S. 2005. Public Input Competition. Journal of Public Economics. 89(9-10): 1763-1787.

Buettner, T. 2016. Commercial Land Use and Interjurisdictional Competition. FriedrichAlexander-University, Mimeo.

Burchfield, M., Overman, H.G., Puga, D. and Turner, M.A. 2006. Causes of sprawl: a portrait from space. Quarterly Journal of Economics. 121(2): 587-633.

Burnes, D., Neumark, D. and White, M.J. 2012. Fiscal Zoning and Sales Taxes: Do Higher Sales Taxes Lead to More Retailing and Less Manufacturing? NBER Working Papers. No. 16932.

Cheshire, P. 2009. Urban Containment, Housing Affordability and Price Stability Irreconcilable Goals, Paper No SERCPP004, LSE.

Cheshire, P., 2013. Land market regulation: market versus policy failures. Journal of Property Research. 30(3): 170-188.

Cheshire, P.C. and Hilber, C.A.L. 2008. Office space supply restrictions in Britain: The political economy of market revenge. Economic Journal. 118(529): F185-221. 
Cheshire, P., Hilber, C.A.L. and Koster, H.R.A. 2017. Empty homes, longer commutes: the unintended consequences of more restrictive local planning. London School of Economics, mimeo, August.

Cheshire, P. and Sheppard, S. 2002. Welfare economics of land use regulation. Journal of Urban Economics. 52: 242-269.

Cheshire, P. and Sheppard, S. 2005. The Introduction of Price Signals into Land Use Planning Decision-making: a proposal. Urban Studies. 42(4): 647-663.

Clifton, K., Ewing R., Knaap, G.J. and Y. Song. 2008. Quantitative Approaches to Urban Form: A Multidisciplinary Review. Journal of Urbanism. 1(1): 17-46.

Coomes, P.A. and Hoyt, W.H. 2008. Income Taxes and the Destination of Movers to Multistate MSAs. Journal of Urban Economics. 63(3): 920-937.

Cunningham, C. 2007. Growth Controls, Real Options, and Land Development. Review of Economics and Statistics. 89(2): 343-358.

Dempsey, J.A. and Plantinga, A.J. 2013. How Well Do Urban Growth Boundaries Contain Development? Results for Oregon using a Difference-in-Difference Estimator. Regional Science and Urban Economics. 43(6): 996-1007.

Elazar, D. J. 1995. From Statism to Federalism: A Paradigm Shift. Publius - The Journal of Federalism. 25(2): 5-18.

Engle, R., Navarro, P. and Carson, R. 1992. On the Theory of Growth Controls. Journal of Urban Economics. 32(3): 269-283.

Fajgelbaum, P. D., Morales, E., Suárez Serrato, J.C., and Zidar, O.M. 2015. State Taxes and Spatial Misallocation. NBER Working Paper. No. w21760.

Fenge, R., Ehrlich M. V. and Wrede, M. 2009. Public Input Competition and Agglomeration. Regional Science and Urban Economics. 93(5): 621-631.

Fischel, W.A. 1990. Do Growth Controls Matter? A Review of Empirical Evidence on the Effectiveness and Efficiency of Local Government Land Use Regulation. Cambridge, MA: Lincoln Institute for Land Policy.

Fischel, W.A. 2000. Zoning and Land Use Regulation. In: B. Boudewijn, G. De Geest (Eds.), Encyclopedia of Law and Economics, Volume II: Civil Law and Economics, Edward Elgar, Cheltenham, 403-423.

Galster, G., Hanson, R., Ratcliffe, M.R., Wolman, H., Coleman, S. and Freihage, J. 2001. Wrestling Sprawl to the Ground: Defining and Measuring an Elusive Concept. Housing Policy Debate. 12(4): 681-717.

Geshkov, M. V. and De Salvo, J. S. 2012. The Effect of Land use Controls on the Spatial Size of U.S. Urbanized Areas. Journal of Regional Science. 52: 648-675. 
Girouard, N., Kennedy M, van der Noord P. and Andé, C. 2006. Recent House Price Developments: The Role of Fundamentals. OECD Economics Department Working Papers No. 475. OECD.

Glaeser, E.L., Gyourko, J. and Saks, R.E. 2005. Why is Manhattan so Expensive? Regulation and the Rise in Housing Prices. Journal of Law and Economics. 48(2): 331-369.

Glaeser, E.L., and Kahn, M.E. 2004. Sprawl and Urban Growth, In: J. Vernon Henderson and Jacques-François Thisse (Eds). Handbook of Regional and Urban Economics. Elsevier, Volume 4, Ch. 56: 2481-2527.

Glaeser, E.L. and Ward, B.A. 2009. The Causes and Consequences of Land Use Regulation: Evidence from Greater Boston. Journal of Urban Economics. 65(3): 265-278.

Gyourko, J. and Molloy, R. 2015. Regulation and Housing Supply, In: G. Duranton, J.V. Henderson and W. Strange (Eds). Handbook of Regional and Urban Economics. Elsevier. Volume 5A-5B, Ch. 19: 1289-1337.

Hauptmeier, S., Mittermaier, F. and Rincke, J. 2012. Fiscal Competition over Taxes and Public Inputs. Regional Science and Urban Economics. 42: 407-419.

Helsley, R.W and Strange, W.C. 1995. Strategic Growth Controls. Regional Science and Urban Economics. 25(4): 435-460.

Heyndels, B. and Vuchelen, J. 1998. Tax Mimicking among Belgian Municipalities. National Tax Journal. 51: 89-101.

Hilber, C.A.L. 2017. The Economic Implications of House Price Capitalization: A Synthesis. Real Estate Economics. 45(2): 301-339.

Hilber, C.A.L. and Robert-Nicoud, F. 2013. On the Origins of Land Use Regulations: Theory and Evidence from US Metro Areas. Journal of Urban Economics. 75(1): 29-43.

Hilber, C.A.L. and Vermeulen, W. 2016. The Impact of Supply Constraints on House Prices in England. Economic Journal. 126(591): 358-405.

Hooghe, L., Marks, G., Schakel A. H., Chapman Osterkatz S., Niedzwiecki, S., and ShairRosenfield, S. 2016. A Postfunctionalist Theory of Governance. Volume I: Measuring Regional Authority. Oxford: Oxford University Press.

Hsieh, C.T. and Moretti, E. (2015). Why Do Cities Matter? Local Growth and Aggregate Growth. NBER Working Paper, No. 21154, May.

Irwin, E.G. and Bockstael, N.E. 2004. Land Use Externalities, Open Space Preservation, and Urban Sprawl. Regional Science and Urban Economics. 34(6): 705-725.

Jacob, B. and McMillen, D. 2015. Border Effects in Suburban Land Use. National Tax Journal. Special Issue 68(3s): 855-873. 
Knoll, K., Schularick, M., and Steger, T. 2017. No Price Like Home: Global House Prices, 1870-2012. American Economic Review, 107(2): 331-53.

Mayer, C.J. and Somerville, C.T. 2000. Land Use Regulation and New Construction. Regional Science and Urban Economics. 30(6): 639-662.

McConnell, V. Walls, M. and Kopits, E. 2006. Zoning, TDRs and the Density of Development. Journal of Urban Economics. 59(3): 440-457.

Moss, W.G. 1977. Large Lot Zoning, Property Taxes, and Metropolitan Area. Journal of Urban Economics. 4(4): 408-427.

Nechyba, T. and Walsh, R. 2004. Urban Sprawl. Journal of Economic Perspectives. 18(4), 177-200.

Pasha, H.A. 1996. Suburban Minimum Lot Zoning and Spatial Equilibrium. Journal of Urban Economics. 40(1): 1-12.

Quigley, J. M. and Raphael, S. 2005. Regulation and the High Cost of Housing in California. American Economic Review. 95(2): 323-328.

Quigley, J., M. and Rosenthal, L. 2005. The Effects of Land Use Regulation on the Price of Housing: What Do We Know? What Can We Learn? Cityscape. 8(1): 69-137.

Rohlin, S., Rosenthal, S. and Ross, A. 2014. Tax Avoidance and Business Location in a State Border Model. Journal of Urban Economics. 83: 34-49.

Saiz, A. 2010. The Geographic Determinants of Housing Supply. Quarterly Journal of Economics. 125(3): 1253-1296.

Silva, E. and Acheampong, R. 2015. Developing an Inventory and Typology of Land-Use Planning Systems and Policy Instruments in OECD Countries. OECD Environment Working Papers, No. 94, OECD Publishing, Paris.

Song, Y. and Knaap, G-J. 2004. Measuring Urban Form: Is Portland Winning the War on Sprawl? Journal of the American Planning Association. 70(2): 210-225.

Song, Y. and Zenou, Y. 2006. Property Tax and Urban Sprawl: Theory and Implications for US Cities. Journal of Urban Economics. 60(3): 519-534.

Tiebout, C.M. 1956. A Pure Theory of Local Expenditures. Journal of Political Economy. 64: 416-424.

Treisman, D. 2008. Decentralization Dataset. Available at: http://www.sscnet.ucla.edu/ polisci/faculty/treisman/

Turner, M.A., Haughwout, A. and Van Der Klaauw. 2014. Land use regulation and welfare. Econometrica 82(4): 1341-1403. 
Voith, R., Gyourko, J. 2002. Capitalization of Federal Taxes, the Relative Price of Housing, and Urban Form: Density and Sorting Effects. Regional Science and Urban Economics. 32(6): 673-690.

Wassmer, R. W. 2000. Urban Sprawl in a U.S. Metropolitan Area: Ways to Measure and a Comparison of the Sacramento Area to Similar Metropolitan Areas in California and the U.S. CSUS Public Policy and Administration Working Paper, No. 2000-03. 


\title{
TABLES
}

\author{
Table 1
}

Summary Statistics

\begin{tabular}{lcccc}
\hline \hline & Mean & Std. Dev & Min & Max \\
\hline Urban sprawl & 0.399 & 0.081 & 0.222 & 0.517 \\
Urban sprawl outside FUA & 0.419 & 0.120 & 0.215 & 0.671 \\
Urban sprawl inside FUA & 0.408 & 0.090 & 0.222 & 0.555 \\
Central and Eastern Europe & 0.417 & - & 0 & 1 \\
Ln(GDP per capita) & 9.683 & 0.704 & 8.305 & 10.930 \\
Subnational autonomy & 0.242 & - & 0 & 1 \\
Federal constitution & 0.182 & - & 0 & 1 \\
No. tiers & 3.328 & 0.617 & 2 & 4.5 \\
Regional autonomy index & 10.116 & 10.543 & 0 & 35.642 \\
No. municipalities & 3.752 & 6.660 & 0.011 & 36.703 \\
Population & 14.217 & 20.231 & 0.031 & 80.600 \\
\hline \hline
\end{tabular}

Notes: Population is measured in millions, number of municipalities in thousands, per-capita GDP is adjusted by purchasing power parity and measured in the year 2000. In total we have 36 country with non-missing information about urban sprawl. Information on the decentralization measures is missing for LIE, MNE, and SRB; information about the number of municipalities is missing for ALB, BIH, MNE such that we have in total 31 countries entering our benchmark regression specification.

Table 2

Determinants of Sprawl

\begin{tabular}{|c|c|c|c|c|c|}
\hline & \multicolumn{5}{|c|}{ Dependent Variable: Residential Sprawl } \\
\hline & (1) & (2) & (3) & (4) & (5) \\
\hline Subnational autonomy & $\begin{array}{c}0.095 * * * \\
(0.025)\end{array}$ & & & & $\begin{array}{c}0.116 * * * \\
(0.025)\end{array}$ \\
\hline Federal constitution & & $\begin{array}{c}0.074 * * * \\
(0.026)\end{array}$ & & & \\
\hline No. tiers & & & $\begin{array}{c}0.049 * * \\
(0.021)\end{array}$ & & \\
\hline Regional autonomy index & & & & $\begin{array}{l}0.002 * \\
(0.001)\end{array}$ & \\
\hline No. municipalities & & & & & $\begin{array}{c}0.005^{* * * *} \\
(0.001)\end{array}$ \\
\hline Population & & & & & $\begin{array}{c}-0.0014 * \\
(0.001)\end{array}$ \\
\hline Central and Eastern Europe & $\begin{array}{c}0.131 * * \\
(0.056)\end{array}$ & $\begin{array}{c}0.140 * * \\
(0.058)\end{array}$ & $\begin{array}{c}0.179 * * * \\
(0.051)\end{array}$ & $\begin{array}{c}0.143 * * \\
(0.061)\end{array}$ & $\begin{array}{c}0.120 * * \\
(0.058)\end{array}$ \\
\hline Log GDP per capita (2000) & $\begin{array}{c}0.006 \\
(0.039)\end{array}$ & $\begin{array}{c}0.030 \\
(0.046)\end{array}$ & $\begin{array}{c}0.065 \\
(0.046)\end{array}$ & $\begin{array}{c}0.030 \\
(0.049)\end{array}$ & $\begin{array}{l}-0.007 \\
(0.042)\end{array}$ \\
\hline Constant & $\begin{array}{c}0.259 \\
(0.408) \\
\end{array}$ & $\begin{array}{c}0.034 \\
(0.475)\end{array}$ & $\begin{array}{l}-0.472 \\
(0.495)\end{array}$ & $\begin{array}{c}0.018 \\
(0.504)\end{array}$ & $\begin{array}{c}0.394 \\
(0.437) \\
\end{array}$ \\
\hline Observations & 31 & 31 & 31 & 31 & 31 \\
\hline Adjusted R-squared & 0.44 & 0.34 & 0.36 & 0.30 & 0.51 \\
\hline
\end{tabular}

Notes: Robust standard errors in parentheses. $* * * \mathrm{p}<0.01, * * \mathrm{p}<0.05, * \mathrm{p}<0.1$. Population is measured in millions, number of municipalities in thousands, per-capita GDP is adjusted by purchasing power parity. 
Table 3

Determinants of Sprawl outside Functional Urban Areas

\begin{tabular}{|c|c|c|c|c|c|}
\hline & \multicolumn{5}{|c|}{ Dependent Variable: Sprawl outside Functional Urban Areas } \\
\hline & $(1)$ & (2) & (3) & (4) & $(5)$ \\
\hline Subnational autonomy & $\begin{array}{c}0.092 * * * \\
(0.029)\end{array}$ & & & & $\begin{array}{c}0.097 * * \\
(0.036)\end{array}$ \\
\hline Federal constitution & & $\begin{array}{c}0.073 * * \\
(0.031)\end{array}$ & & & \\
\hline No. tiers & & & $\begin{array}{c}0.067 * * * \\
(0.023)\end{array}$ & & \\
\hline Regional autonomy index & & & & $\begin{array}{l}0.003 * \\
(0.001)\end{array}$ & \\
\hline No. municipalities & & & & & $\begin{array}{c}0.003 \\
(0.002)\end{array}$ \\
\hline Population & & & & & $\begin{array}{l}-0.0003 \\
(0.001)\end{array}$ \\
\hline Central and Eastern Europe & $\begin{array}{c}0.082 \\
(0.075)\end{array}$ & $\begin{array}{c}0.092 \\
(0.076)\end{array}$ & $\begin{array}{c}0.152 * * \\
(0.059)\end{array}$ & $\begin{array}{c}0.101 \\
(0.082)\end{array}$ & $\begin{array}{c}0.086 \\
(0.083)\end{array}$ \\
\hline Log GDP per capita (2000) & $\begin{array}{l}-0.036 \\
(0.052)\end{array}$ & $\begin{array}{l}-0.014 \\
(0.052)\end{array}$ & $\begin{array}{c}0.034 \\
(0.047)\end{array}$ & $\begin{array}{l}-0.013 \\
(0.056)\end{array}$ & $\begin{array}{l}-0.037 \\
(0.059)\end{array}$ \\
\hline Constant & $\begin{array}{c}0.710 \\
(0.543) \\
\end{array}$ & $\begin{array}{c}0.491 \\
(0.550) \\
\end{array}$ & $\begin{array}{l}-0.205 \\
(0.493) \\
\end{array}$ & $\begin{array}{c}0.464 \\
(0.592) \\
\end{array}$ & $\begin{array}{c}0.709 \\
(0.618) \\
\end{array}$ \\
\hline Observations & 31 & 31 & 31 & 31 & 31 \\
\hline Adjusted R-squared & 0.29 & 0.22 & 0.33 & 0.22 & 0.28 \\
\hline
\end{tabular}

Notes: Robust standard errors in parentheses. $* * * \mathrm{p}<0.01, * * \mathrm{p}<0.05, * \mathrm{p}<0.1$. Population is measured in millions, number of municipalities in thousands, per-capita GDP is adjusted by purchasing power parity. 


\section{FIGURES}

Figure 1

Cross-Sectional Variation in Aggregate Urban Sprawl

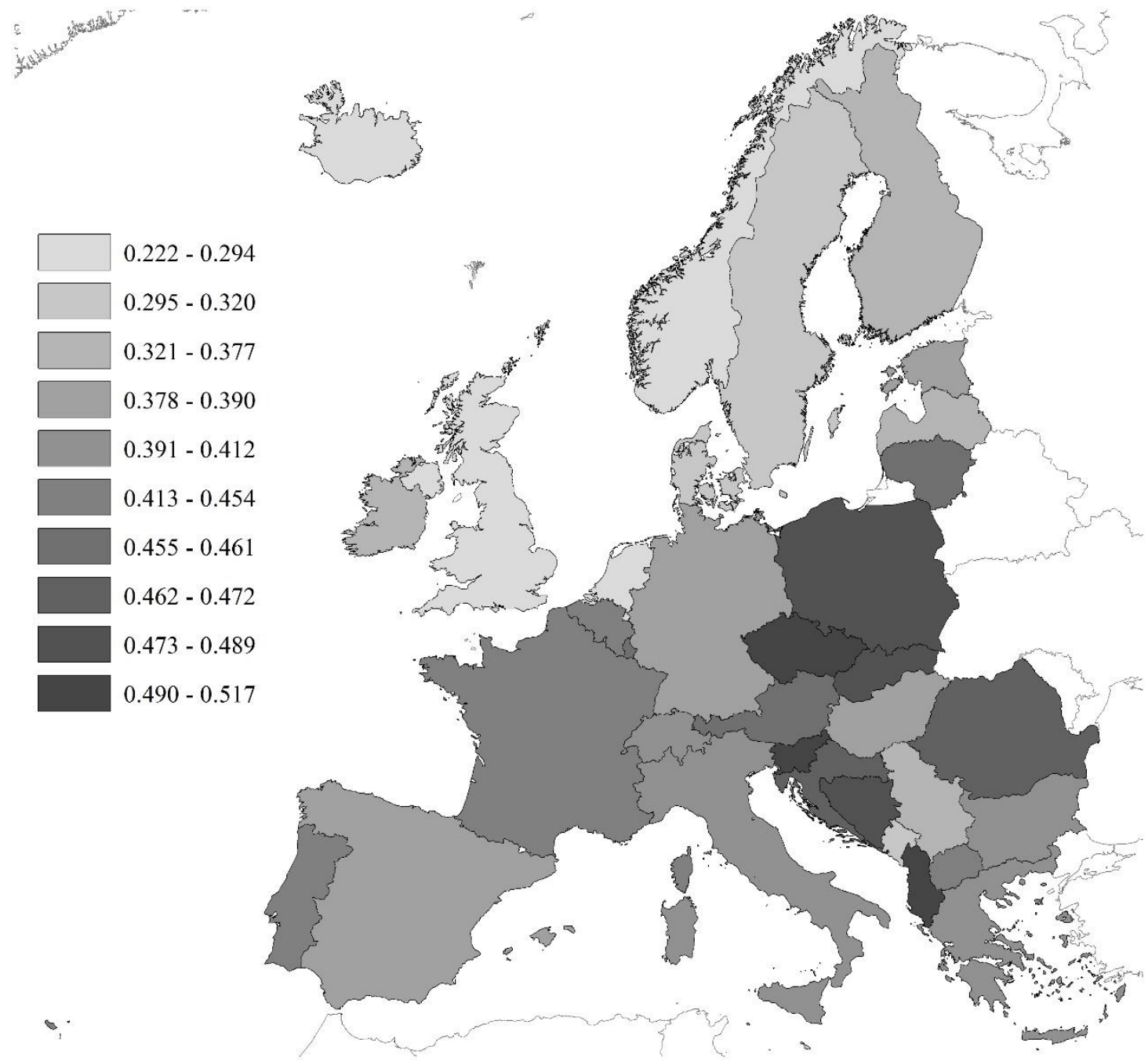


Figure 2

Urban Sprawl outside Functional Urban Areas

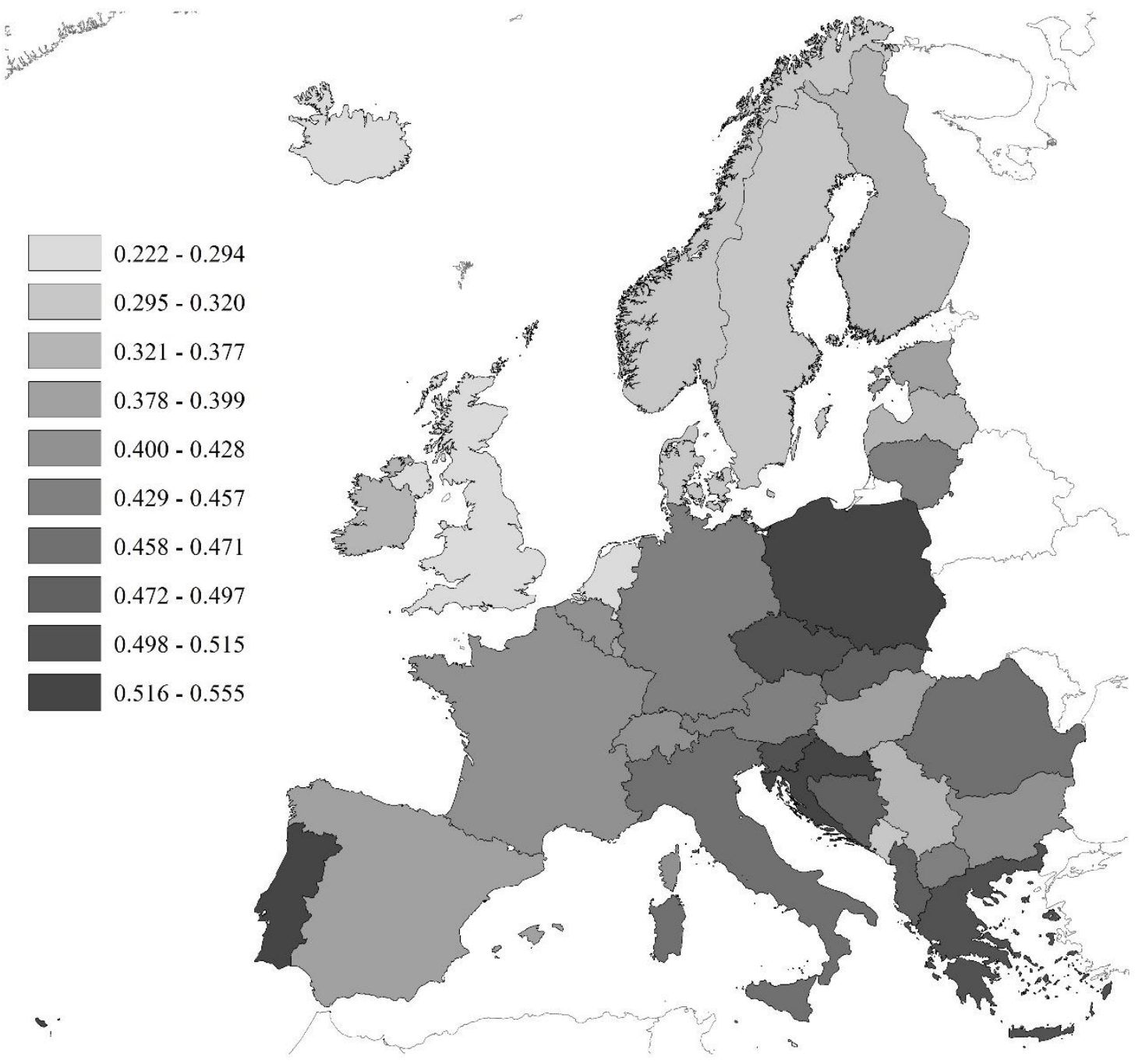


Figure 3

Urban Sprawl 1990-2012: Western European Countries
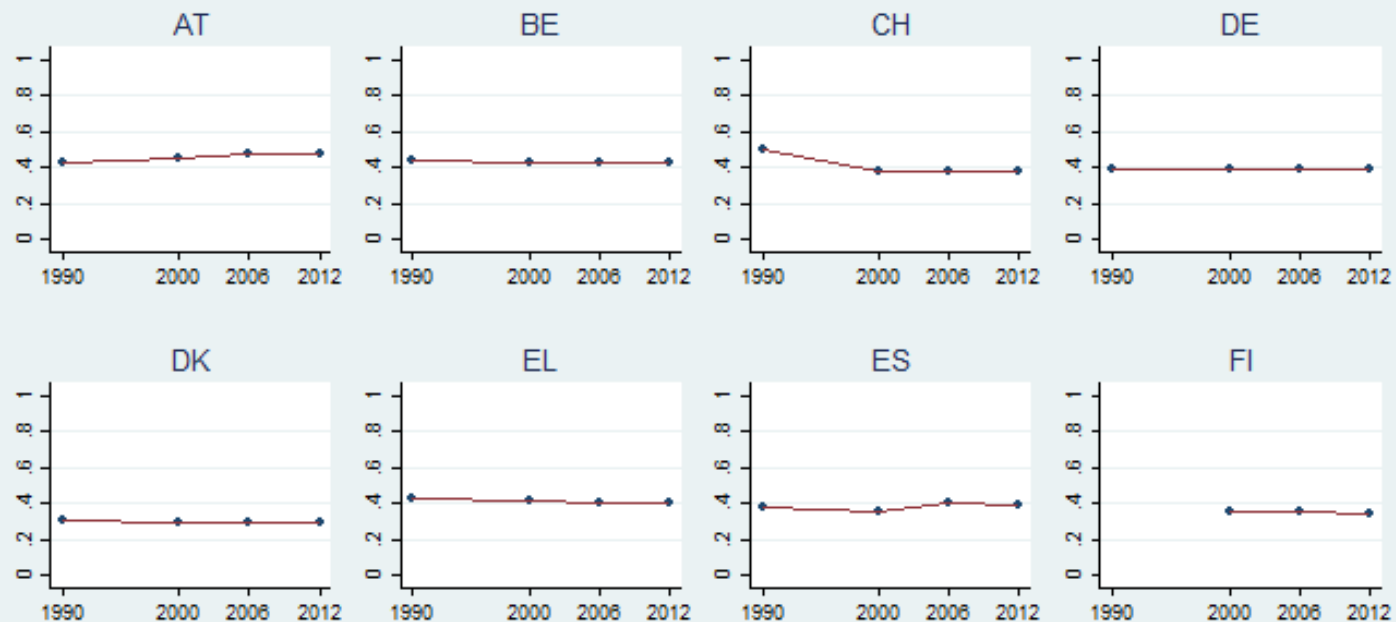

EL

ES

$\mathrm{FI}$
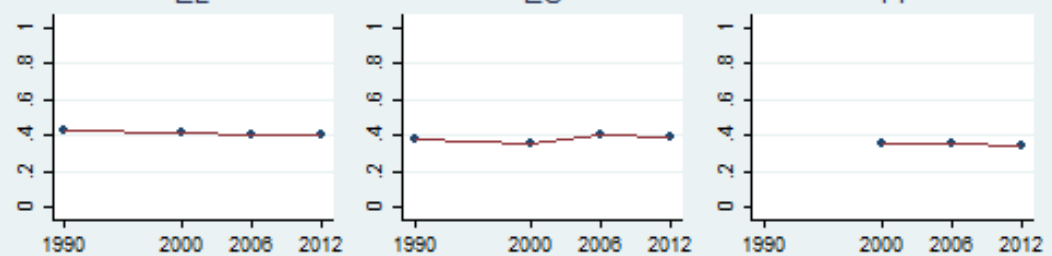

FR

IE

IS

IT
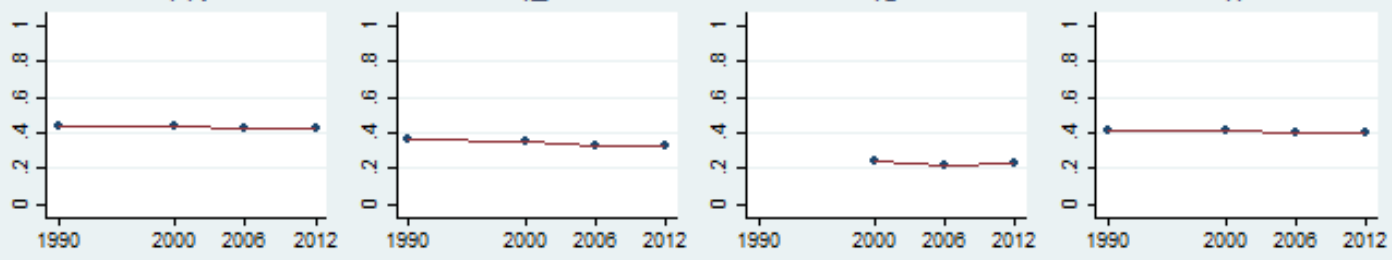

LI

LU

MT

NL
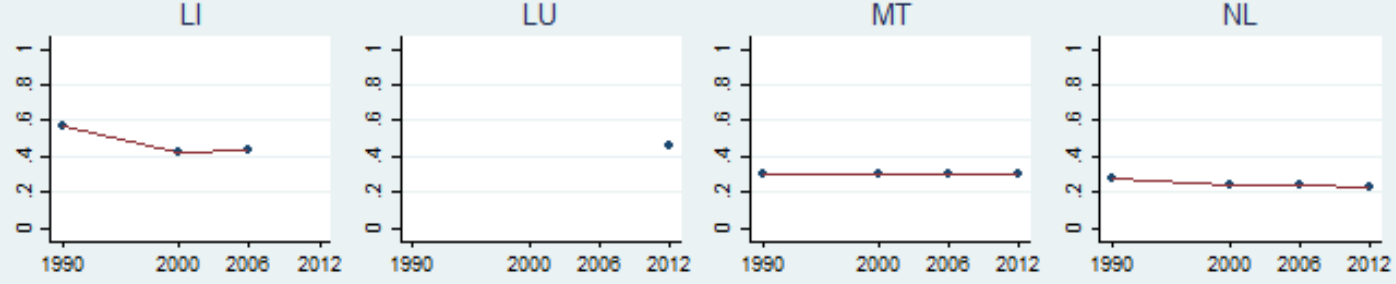

NO

PT

SE
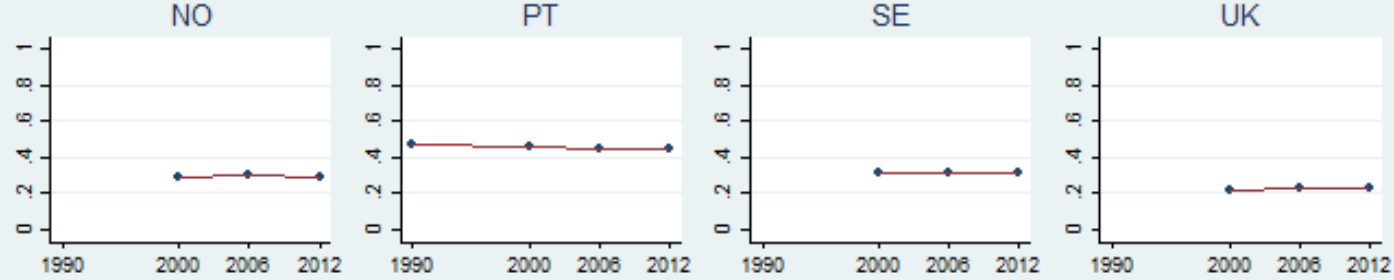
Figure 4

Urban Sprawl 1990-2012: Central and Eastern European Countries

$\mathrm{AL}$

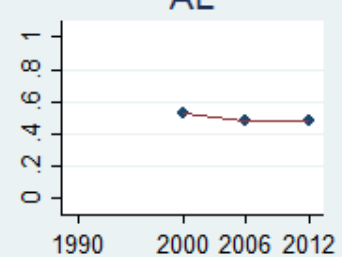

EE

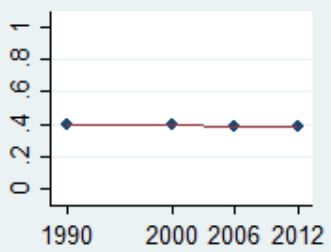

LV

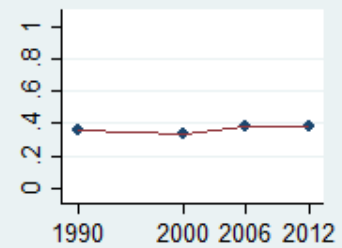

RO

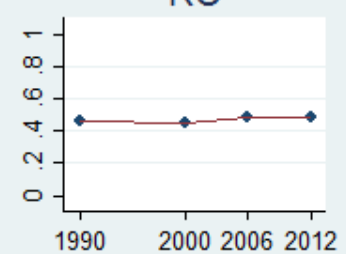

BA

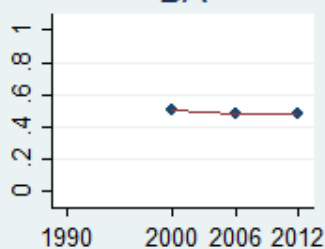

HR

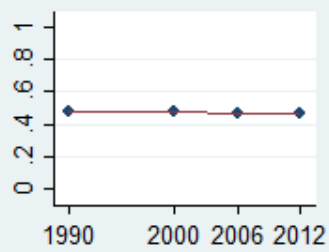

ME

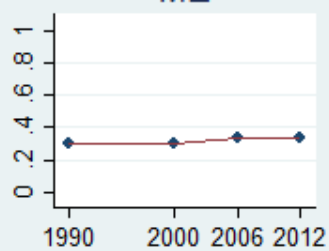

RS

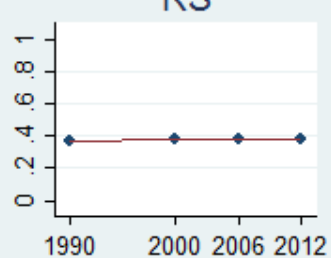

BG

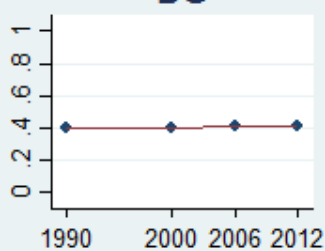

HU

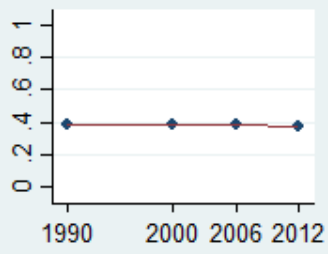

MK

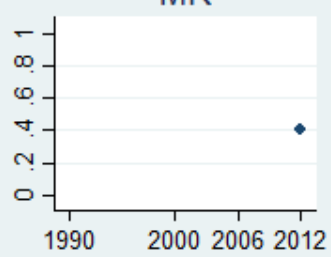

SI

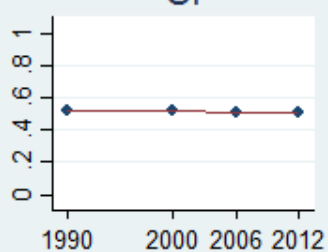

CZ

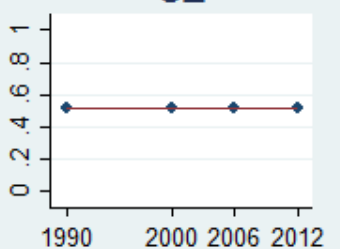

LT

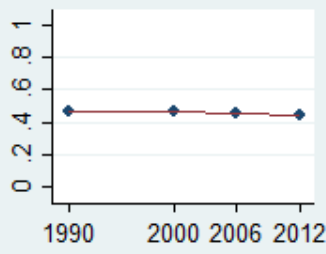

PL

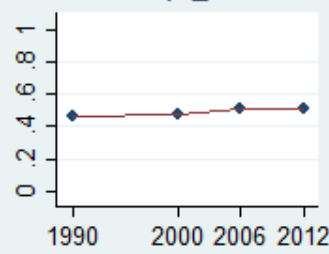

SK

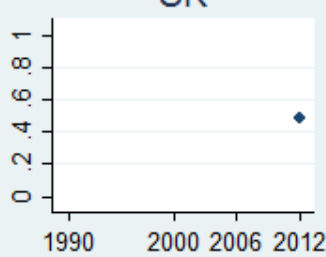


Figure 5

Change in Real House Prices (in \%) vs. Urban Sprawl

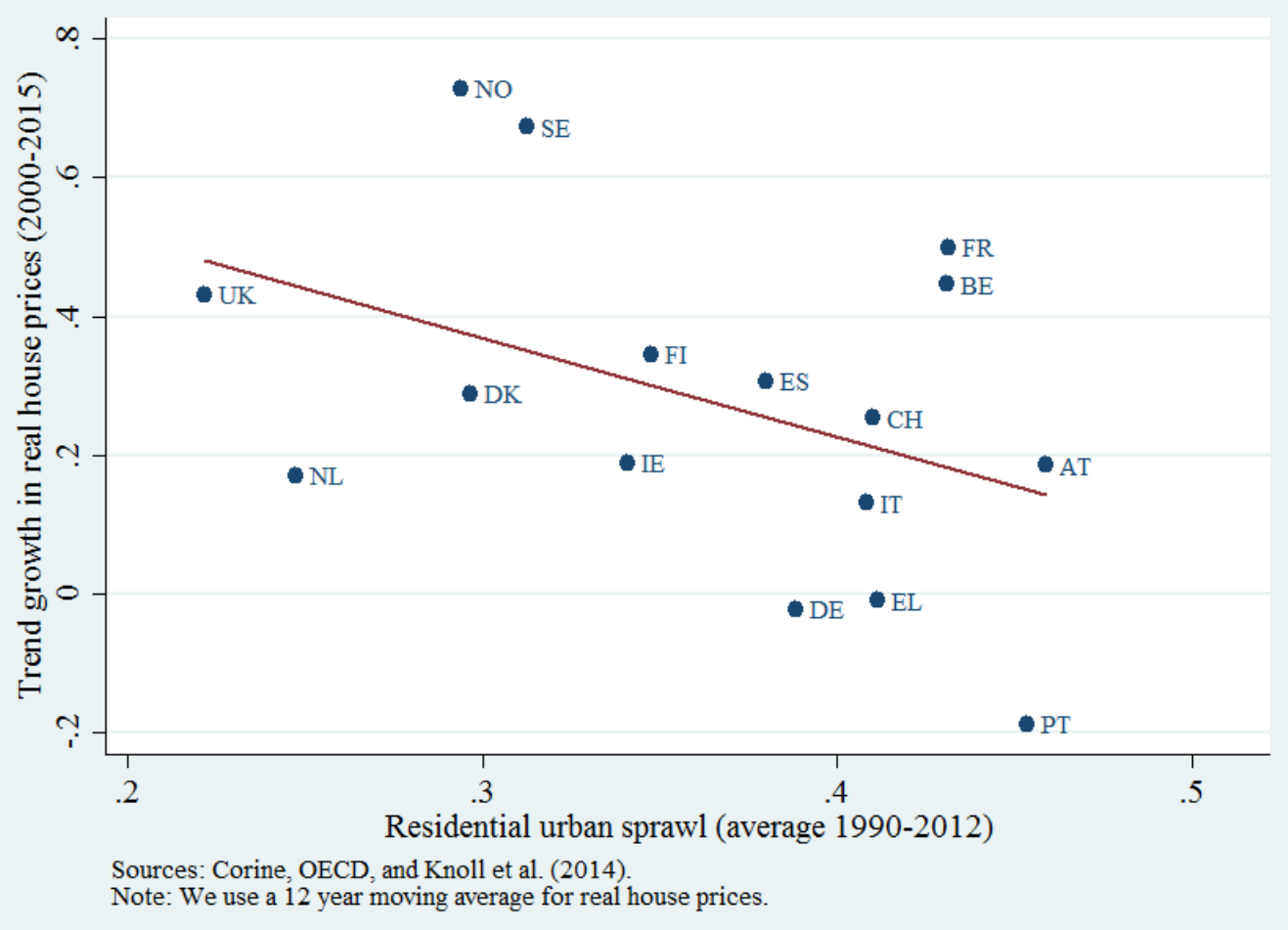

Figure 6

Change in Real House Prices (in \%) vs. Sprawl outside Functional Urban Regions

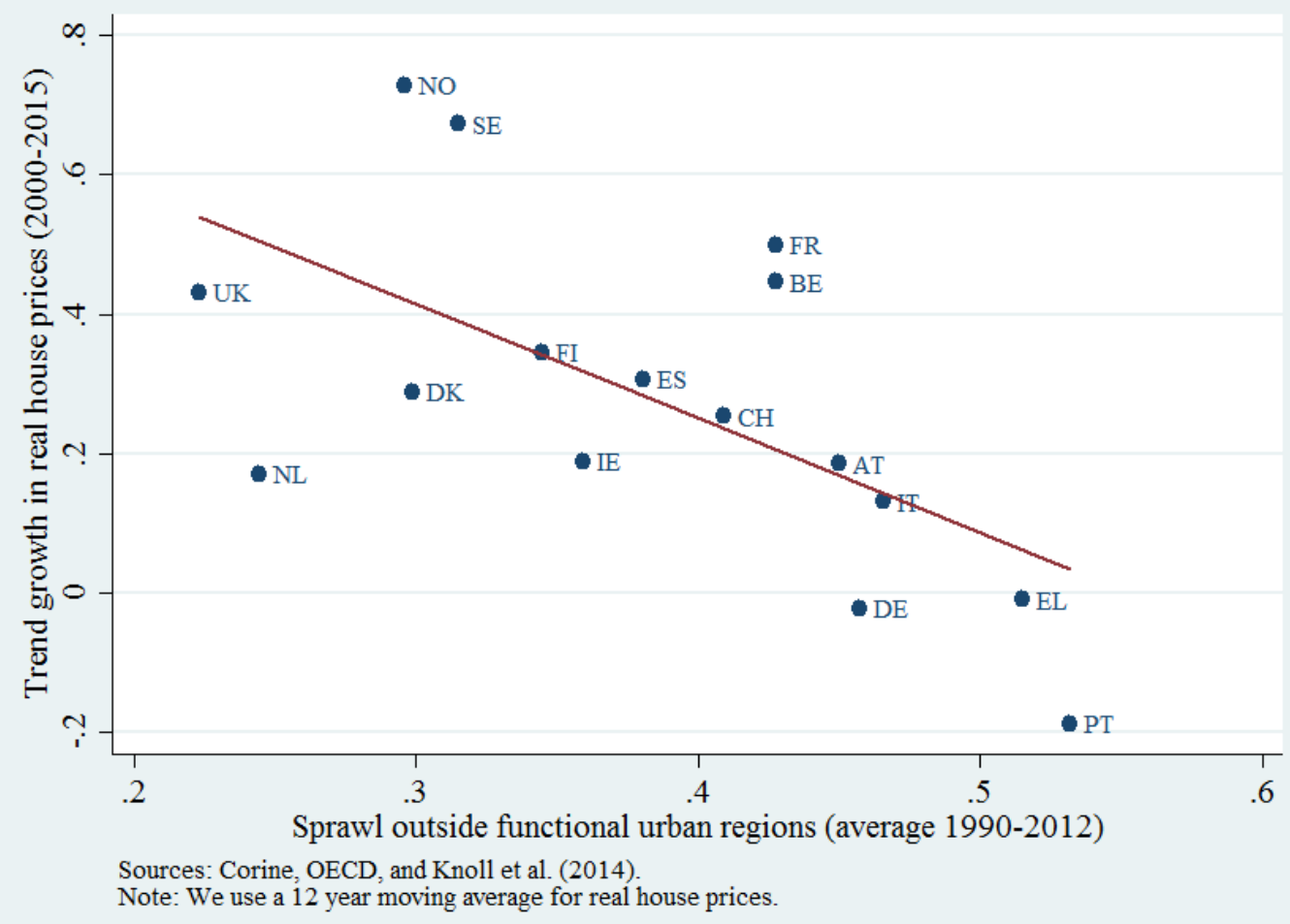


Figure 7

Change in House Price to Income-Ratio (in \%) vs. Urban Sprawl

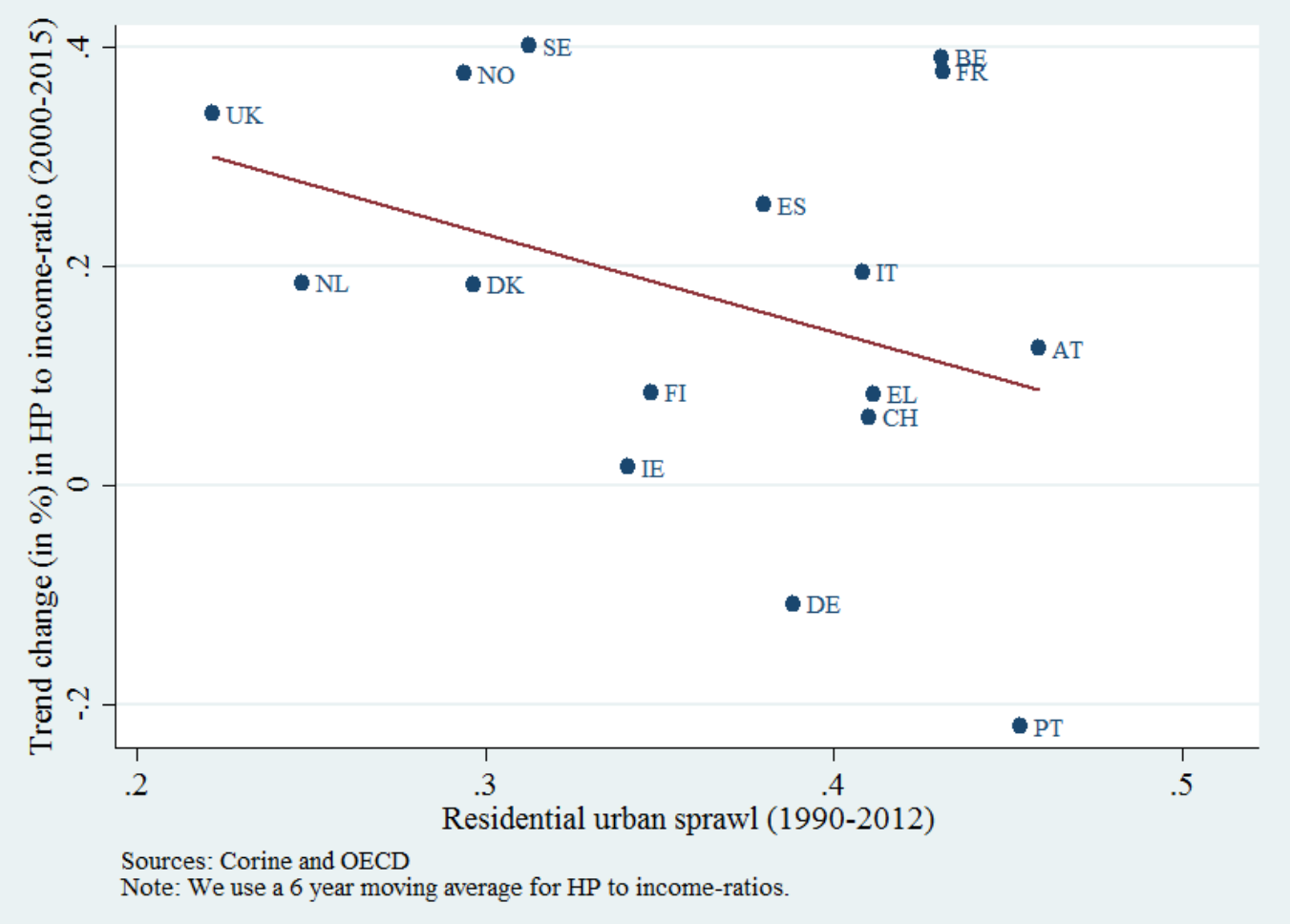

Figure 8

Change in House Price to Income-Ratio (in \%) vs. Sprawl outside Functional Urban Regions

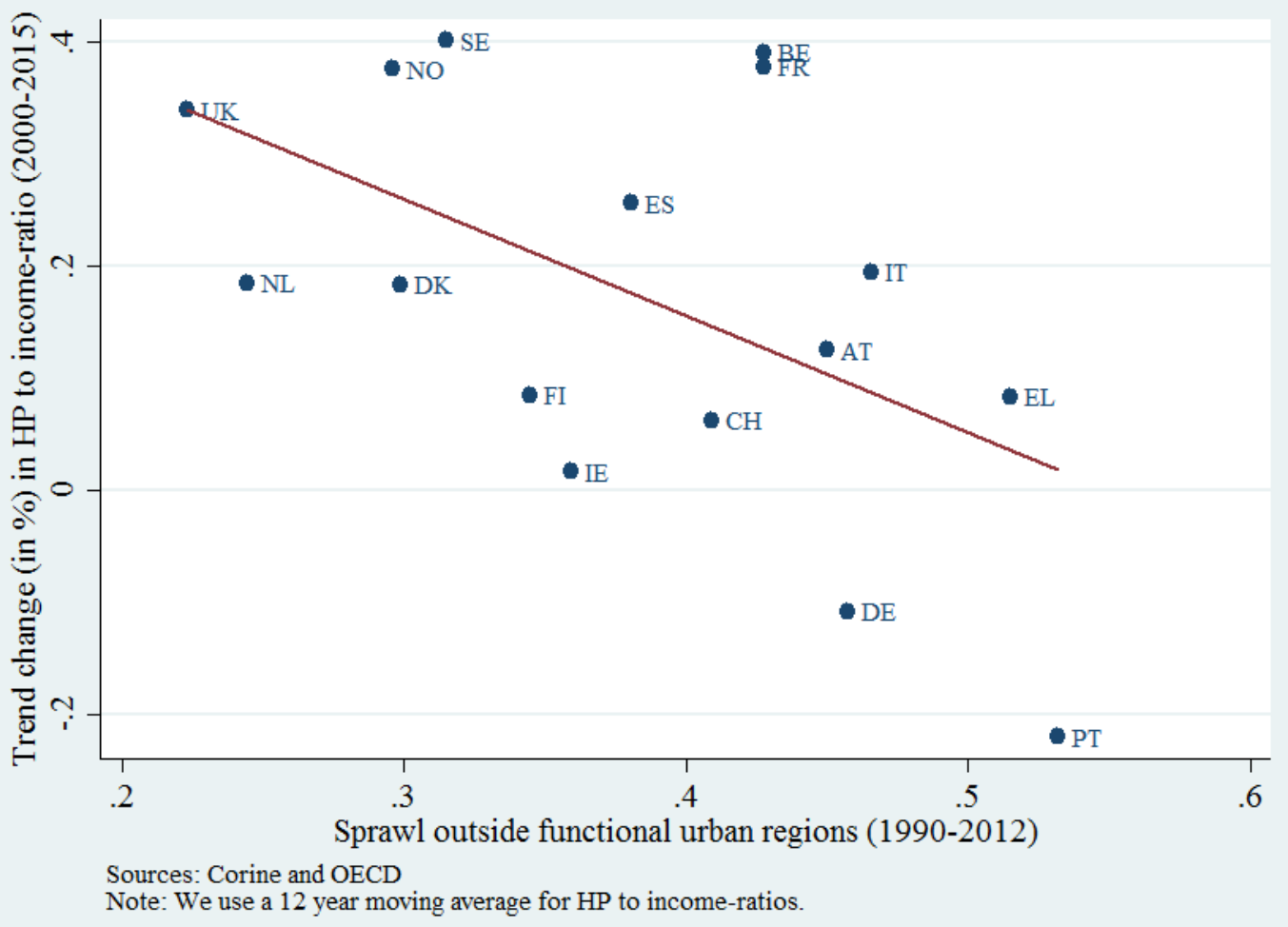


APPENDICES

\section{Appendix A: Appendix Tables}

Table A1

Data Sources and Complementary Information

\begin{tabular}{|c|c|}
\hline Type of data & Source \\
\hline Land cover & $\begin{array}{l}\text { Corine Land Cover (CLC) inventory: } \\
\text { http://land.copernicus.eu/pan-european/corine-land-cover }\end{array}$ \\
\hline Decentralization & $\begin{array}{l}\text { Hooghe et al. }(2016) \text { - Regional Autonomy Index (RAI) : } \\
\text { https://www.arjanschakel.nl//regauth_dat.html } \\
\text { Treisman (2008): } \\
\text { http://www.sscnet.ucla.edu/polisci/faculty/treisman/Papers/Decentralization.xls }\end{array}$ \\
\hline $\begin{array}{l}\text { Institutional } \\
\text { fragmentation }\end{array}$ & $\begin{array}{l}\text { Eurostat municipality boundaries: } \\
\text { http://ec.europa.eu/eurostat/web/gisco/geodata/reference-data/administrative- } \\
\underline{\text { units-statistical-units/communes\#communes13 }}\end{array}$ \\
\hline $\begin{array}{l}\text { Functional } \\
\text { urban areas }\end{array}$ & $\begin{array}{l}\text { Eurostat urban audit: } \\
\text { http://ec.europa.eu/eurostat/web/gisco/geodata/reference-data/administrative- } \\
\underline{\text { units-statistical-units/urban-audit }}\end{array}$ \\
\hline & $\begin{array}{l}\text { Additional information: } \\
\text { http://ec.europa.eu/eurostat/statistics- } \\
\text { explained/index.php/Archive:European_cities_\%E2\%80\%93 the_EU- } \\
\text { OECD_functional_urban_area_definition }\end{array}$ \\
\hline House prices & $\begin{array}{l}\text { OECD house price indices: } \\
\text { https://stats.oecd.org/Index.aspx?DataSetCode=HOUSE_PRICES }\end{array}$ \\
\hline Others & $\begin{array}{l}\text { World Bank 'world development indicators' } \\
\text { (GDP per capita, population): } \\
\text { https://data.worldbank.org/data-catalog/world-development-indicators }\end{array}$ \\
\hline
\end{tabular}

Note: Hyperlinks last accessed on October 16, 2017. 
Table A2

Land Cover Classification

\begin{tabular}{|c|c|c|}
\hline CLC code & Label & Class (own definition) \\
\hline 111 & Continuous urban fabric & \multirow{2}{*}{ Residential Developed } \\
\hline 112 & Discontinuous urban fabric & \\
\hline 121 & Industrial or commercial units & \multirow{9}{*}{ Non-Residential Developed } \\
\hline 122 & Road and rail networks and associated land & \\
\hline 123 & Port areas & \\
\hline 124 & Airports & \\
\hline 131 & Mineral extraction sites & \\
\hline 132 & Dump sites & \\
\hline 133 & Construction sites & \\
\hline 141 & Green urban areas & \\
\hline 142 & Sport and leisure facilities & \\
\hline 211 & Non-irrigated arable land & \multirow{18}{*}{ Developable } \\
\hline 212 & Permanently irrigated land & \\
\hline 213 & Rice fields & \\
\hline 221 & Vineyards & \\
\hline 222 & Fruit trees and berry plantations & \\
\hline 223 & Olive groves & \\
\hline 231 & Pastures & \\
\hline 241 & Annual crops associated with permanent crops & \\
\hline 242 & Complex cultivation patterns & \\
\hline 243 & Land principally occupied by agriculture & \\
\hline 244 & Agro-forestry areas & \\
\hline 311 & Broad-leaved forest & \\
\hline 312 & Coniferous forest & \\
\hline 313 & Mixed forest & \\
\hline 321 & Natural grasslands & \\
\hline 322 & Moors and heathland & \\
\hline 323 & Sclerophyllous vegetation & \\
\hline 324 & Transitional woodland-shrub & \\
\hline 331 & Beaches, dunes, sands & \multirow{15}{*}{ Undevelopable } \\
\hline 332 & Bare rocks & \\
\hline 333 & Sparsely vegetated areas & \\
\hline 334 & Burnt areas & \\
\hline 335 & Glaciers and perpetual snow & \\
\hline 411 & Inland marshes & \\
\hline 412 & Peat bogs & \\
\hline 421 & Salt marshes & \\
\hline 422 & Salines & \\
\hline 423 & Intertidal flats & \\
\hline 511 & Water courses & \\
\hline 512 & Water bodies & \\
\hline 521 & Coastal lagoons & \\
\hline 522 & Estuaries & \\
\hline 523 & Sea and ocean & \\
\hline
\end{tabular}


Table A3

Subnational Planning Autonomy

\begin{tabular}{|c|c|c|c|c|c|c|}
\hline & \multicolumn{6}{|c|}{ Dependent Variable: Residential Sprawl } \\
\hline & (1) & (2) & (3) & (4) & (5) & (6) \\
\hline Planning autonomy & $\begin{array}{c}0.004 \\
(0.037)\end{array}$ & $\begin{array}{c}-0.004 \\
(0.029)\end{array}$ & $\begin{array}{c}-0.010 \\
(0.031)\end{array}$ & $\begin{array}{c}0.014 \\
(0.033)\end{array}$ & $\begin{array}{c}0.003 \\
(0.034)\end{array}$ & $\begin{array}{c}0.002 \\
(0.034)\end{array}$ \\
\hline Subnational autonomy & & $\begin{array}{c}0.088 * * * \\
(0.027)\end{array}$ & & & & $\begin{array}{r}0.112 * * * \\
(0.030)\end{array}$ \\
\hline Federal constitution & & & $\begin{array}{c}0.084 * * * \\
(0.029)\end{array}$ & & & \\
\hline No. tiers & & & & $\begin{array}{c}0.080 * * * \\
(0.025)\end{array}$ & & \\
\hline Regional autonomy index & & & & & $\begin{array}{c}0.003 * * \\
(0.001)\end{array}$ & \\
\hline No. municipalities & & & & & & $\begin{array}{c}0.006 * * * \\
(0.002)\end{array}$ \\
\hline Population & & & & & & $\begin{array}{l}-0.002 \\
(0.001)\end{array}$ \\
\hline Central and Eastern Europe & $\begin{array}{c}0.063 \\
(0.085)\end{array}$ & $\begin{array}{c}0.096 \\
(0.095)\end{array}$ & $\begin{array}{c}0.093 \\
(0.091)\end{array}$ & $\begin{array}{l}0.210^{*} \\
(0.101)\end{array}$ & $\begin{array}{c}0.089 \\
(0.105)\end{array}$ & $\begin{array}{c}0.077 \\
(0.089)\end{array}$ \\
\hline Log GDP per capita (2000) & $\begin{array}{l}-0.029 \\
(0.085)\end{array}$ & $\begin{array}{l}-0.026 \\
(0.090)\end{array}$ & $\begin{array}{l}-0.023 \\
(0.088)\end{array}$ & $\begin{array}{c}0.081 \\
(0.100)\end{array}$ & $\begin{array}{l}-0.041 \\
(0.097)\end{array}$ & $\begin{array}{l}-0.052 \\
(0.086)\end{array}$ \\
\hline Constant & $\begin{array}{c}0.647 \\
(0.858)\end{array}$ & $\begin{array}{c}0.596 \\
(0.922)\end{array}$ & $\begin{array}{c}0.567 \\
(0.894)\end{array}$ & $\begin{array}{l}-0.759 \\
(1.052)\end{array}$ & $\begin{array}{c}0.723 \\
(0.991)\end{array}$ & $\begin{array}{c}0.854 \\
(0.886)\end{array}$ \\
\hline Observations & 24 & 24 & 24 & 24 & 24 & 24 \\
\hline Adjusted R-squared & 0.13 & 0.30 & 0.26 & 0.34 & 0.23 & 0.41 \\
\hline
\end{tabular}

Notes: Robust standard errors in parentheses. $* * * \mathrm{p}<0.01, * * \mathrm{p}<0.05, * \mathrm{p}<0.1$. Population is measured in millions, number of municipalities in thousands, per-capita GDP is adjusted by purchasing power parity. Information on planning autonomy stems from Table 2 in Silva and Acheampong (2015). 
Web Appendix: Additional Table and Figures

Table W1

Dataset - Part 1

\begin{tabular}{lrrrrrr}
\hline \hline Country & Sprawl & Sprawl outside & Sprawl inside & Central/Eastern & Ln(GDP/pop) & Autonomy \\
\hline ALB & 0.497 & 0.497 & - & 0 & 8.305 & 0 \\
AUT & 0.459 & 0.450 & 0.505 & 0 & 10.294 & 1 \\
BEL & 0.431 & 0.427 & 0.445 & 0 & 10.250 & 1 \\
BGR & 0.402 & 0.400 & 0.405 & 1 & 8.755 & 0 \\
BIH & 0.489 & 0.489 & 0.516 & 1 & 8.383 & 1 \\
CHE & 0.410 & 0.409 & 0.523 & 0 & 10.449 & 1 \\
CZE & 0.517 & 0.511 & 0.529 & 1 & 9.698 & 0 \\
DEU & 0.388 & 0.457 & 0.442 & 0 & 10.190 & 1 \\
DNK & 0.297 & 0.299 & 0.278 & 0 & 10.294 & 0 \\
ESP & 0.380 & 0.381 & 0.260 & 0 & 9.993 & 1 \\
EST & 0.390 & 0.399 & 0.347 & 1 & 9.181 & 0 \\
FIN & 0.348 & 0.345 & 0.375 & 0 & 10.184 & 0 \\
FRA & 0.431 & 0.428 & 0.452 & 0 & 10.165 & 0 \\
GBR & 0.222 & 0.223 & 0.220 & 0 & 10.270 & 0 \\
GRC & 0.412 & 0.515 & 0.215 & 0 & 9.867 & 0 \\
HRV & 0.472 & 0.519 & 0.510 & 1 & 9.311 & 0 \\
HUN & 0.382 & 0.387 & 0.344 & 1 & 9.401 & 0 \\
IRL & 0.341 & 0.359 & 0.284 & 0 & 10.296 & 0 \\
ISL & 0.228 & 0.222 & 0.631 & 0 & 10.296 & 0 \\
ITA & 0.408 & 0.465 & 0.412 & 0 & 10.190 & 1 \\
LIE & 0.468 & 0.468 & - & 0 & & - \\
LTU & 0.455 & 0.452 & 0.500 & 1 & 9.071 & 0 \\
LUX & 0.461 & 0.394 & 0.504 & 0 & 10.930 & 1 \\
LVA & 0.364 & 0.356 & 0.492 & 1 & 9.008 & 0 \\
MKD & 0.442 & 0.442 & - & 1 & 8.739 & 0 \\
MLT & 0.305 & 0.294 & 0.325 & 0 & 9.939 & 0 \\
MNE & 0.320 & 0.320 & - & 1 & 8.797 & - \\
NLD & 0.248 & 0.244 & 0.273 & 0 & 10.359 & 0 \\
NOR & 0.294 & 0.296 & 0.277 & 0 & 10.513 & 0 \\
POL & 0.489 & 0.555 & 0.544 & 1 & 9.269 & 0 \\
PRT & 0.454 & 0.532 & 0.427 & 0 & 9.790 & 0 \\
ROM & 0.471 & 0.471 & 0.460 & 1 & 8.653 & 0 \\
SRB & 0.377 & 0.377 & 0.671 & 1 & 8.662 & - \\
SVK & 0.487 & 0.495 & 0.440 & 1 & 1 & 0 \\
SVN & 0.513 & 0.510 & 0.537 & 1 & 0.288 & 0 \\
SWE & 0.312 & 0.315 & 0.259 & 0 & & \\
\hline \hline & & & & & 0 & \\
\hline
\end{tabular}


Table W1

Dataset - Part 2

\begin{tabular}{|c|c|c|c|c|c|}
\hline Country & Federal & No. tiers & RAI index & No. municipalities & Population \\
\hline ALB & 0 & 3 & 1.158 & - & 3.044 \\
\hline AUT & 1 & 4 & 22.677 & 2.354 & 7.901 \\
\hline BEL & 1 & 4 & 32.271 & 0.589 & 10.179 \\
\hline BGR & 0 & 4 & 1.100 & 4.617 & 8.344 \\
\hline BIH & 1 & 4 & 28.450 & - & 4.066 \\
\hline CHE & 1 & 3 & 24.855 & 2.453 & 6.986 \\
\hline CZE & 0 & 3 & 5.333 & 6.253 & 10.309 \\
\hline DEU & 1 & 4 & 35.642 & 11.426 & 80.600 \\
\hline DNK & 0 & 3 & 11.568 & 2.178 & 5.266 \\
\hline ESP & 1 & 4 & 30.874 & 8.200 & 40.509 \\
\hline EST & 0 & 3 & 0.000 & 0.230 & 1.446 \\
\hline FIN & 0 & 3 & 4.584 & 0.320 & 5.081 \\
\hline FRA & 0 & 4 & 19.161 & 36.703 & 59.842 \\
\hline GBR & 0 & 4 & 8.845 & 9.499 & 58.442 \\
\hline GRC & 0 & 5 & 6.645 & 0.326 & 10.482 \\
\hline HRV & 0 & 3 & 8.050 & 0.556 & 4.564 \\
\hline HUN & 0 & 3 & 10.538 & 3.154 & 10.348 \\
\hline IRL & 0 & 3 & 1.871 & 3.441 & 3.784 \\
\hline ISL & 0 & 2 & 0.000 & 0.074 & 0.270 \\
\hline ITA & 0 & 4 & 22.055 & 8.092 & 57.155 \\
\hline LIE & - & - & - & 0.011 & 0.031 \\
\hline LTU & 0 & 3 & 2.526 & 0.563 & 3.490 \\
\hline LUX & 0 & 3 & 0.000 & 0.106 & 0.502 \\
\hline LVA & 0 & 3 & 0.286 & 0.587 & 2.439 \\
\hline MKD & 0 & - & 2.000 & 1.817 & 2.061 \\
\hline MLT & 0 & 3 & 0.000 & 0.068 & 0.369 \\
\hline MNE & - & - & 0.000 & - & 0.607 \\
\hline NLD & 0 & 3 & 17.048 & 0.408 & 15.423 \\
\hline NOR & 0 & 3 & 11.581 & 0.428 & 4.393 \\
\hline POL & 0 & 3 & 5.857 & 2.479 & 37.874 \\
\hline PRT & 0 & 4 & 3.706 & 4.260 & 10.171 \\
\hline ROM & 0 & 3 & 8.750 & 3.186 & 22.207 \\
\hline SRB & - & - & 5.400 & 0.205 & 7.517 \\
\hline SVK & 0 & 4 & 8.000 & 2.927 & 5.389 \\
\hline SVN & 0 & 2 & 0.571 & 6.031 & 1.983 \\
\hline SWE & 0 & 3 & 12.645 & 0.290 & 8.743 \\
\hline
\end{tabular}


Figure W1

\section{Federal Constitution}

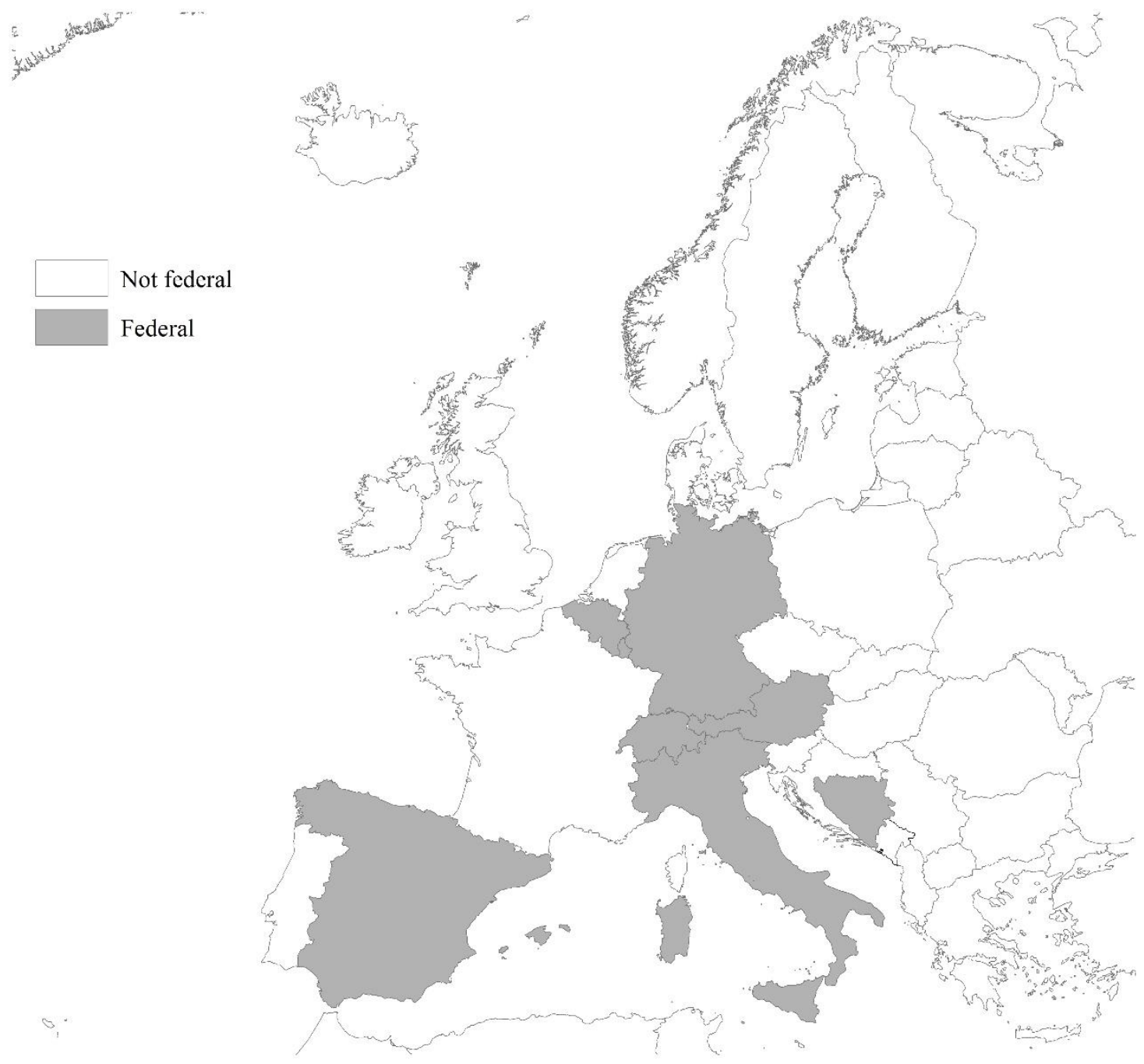


Figure W2

Number of Tiers

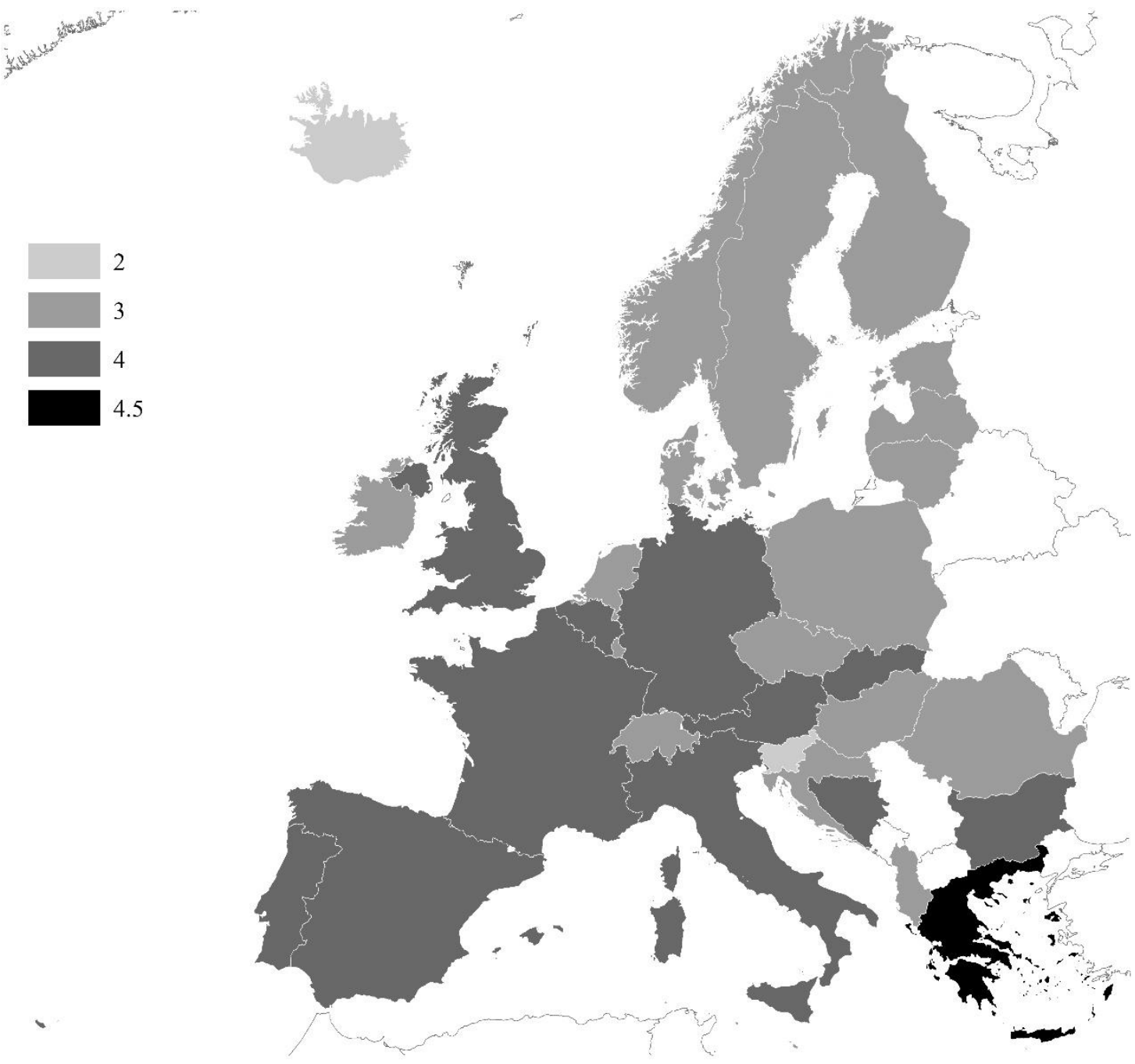


Figure W3

RAI Decentralization Index

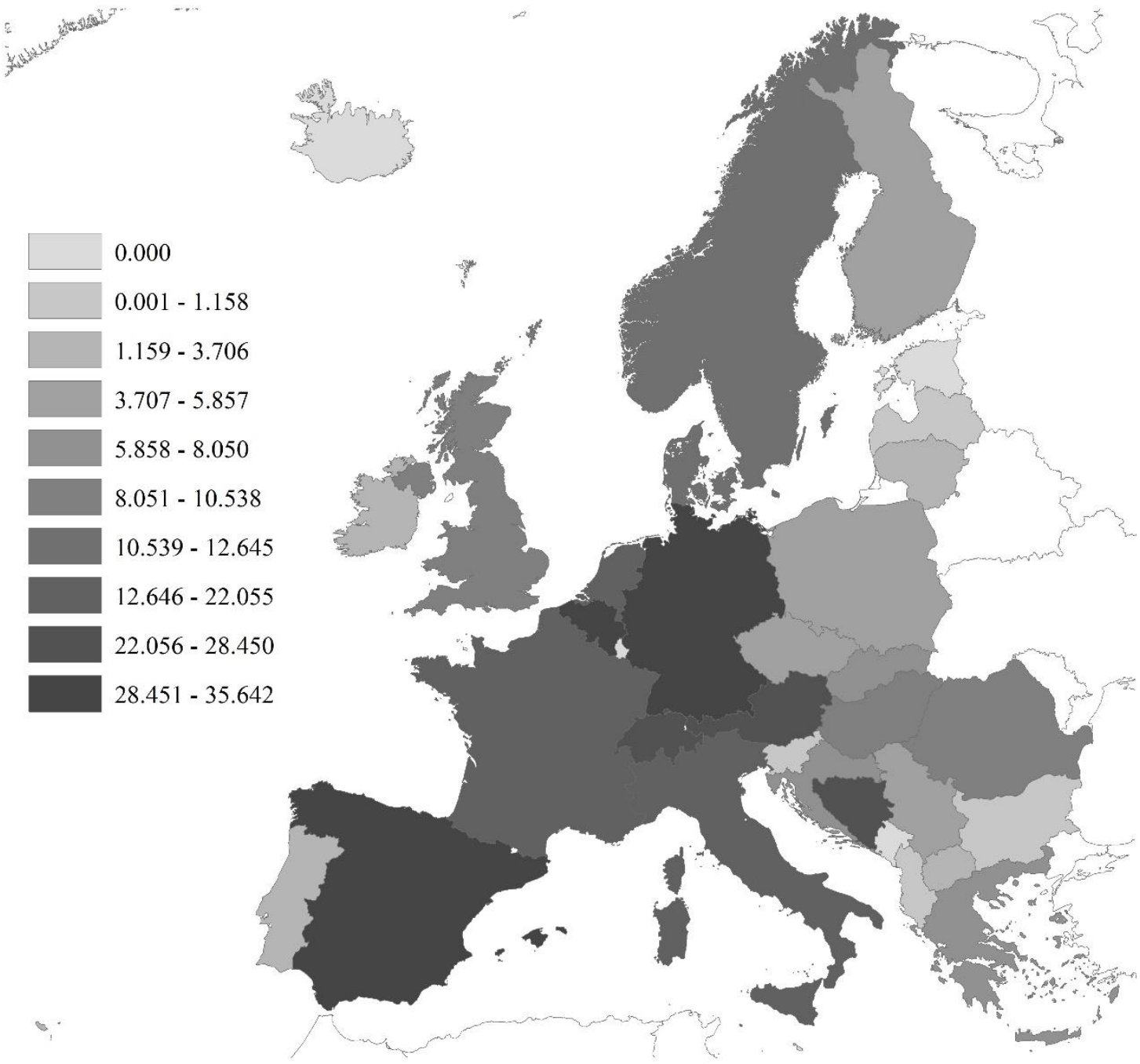


Figure W4

Map of Discontinuity in Municipality Size

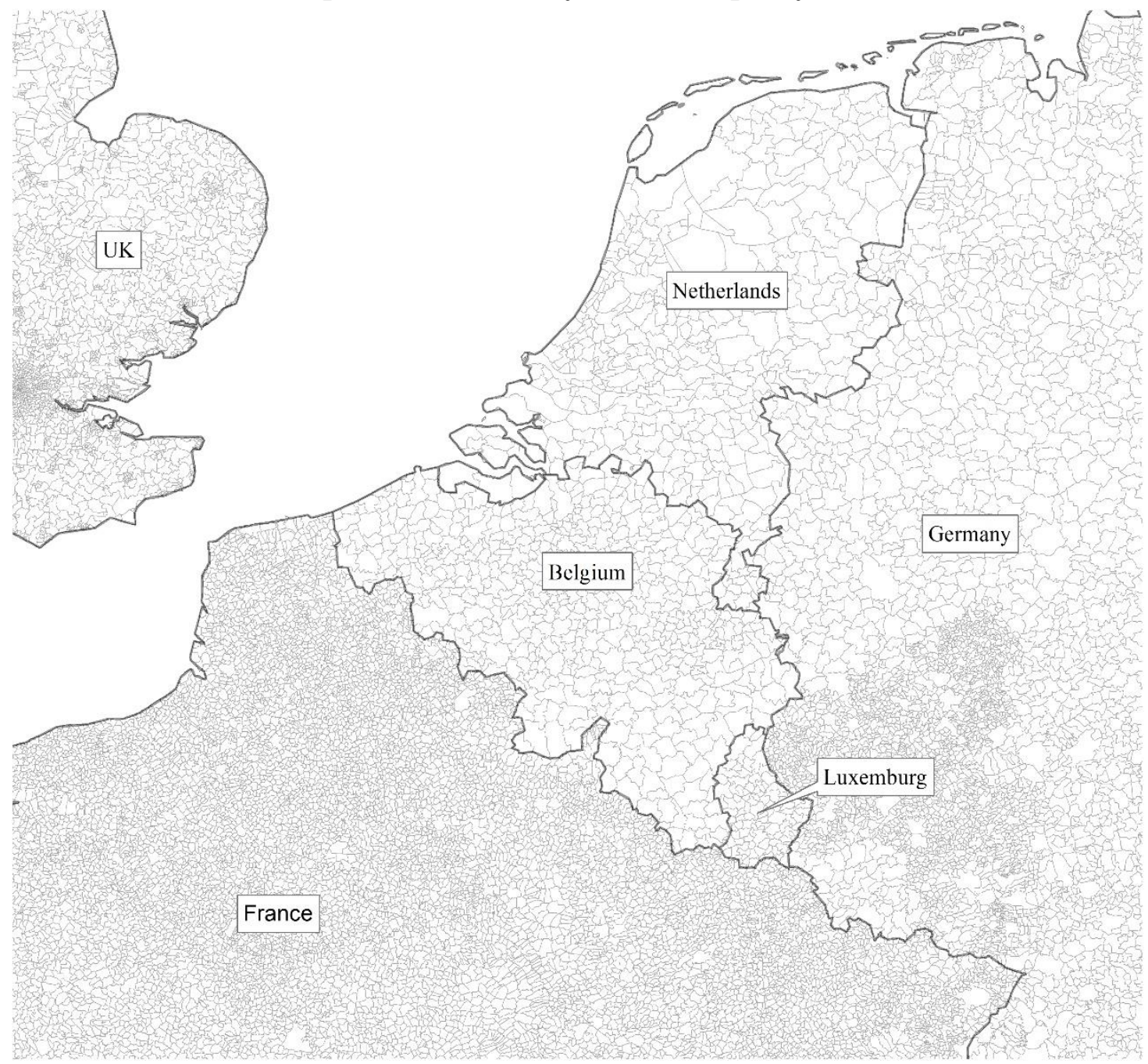




\section{Figure W5}

Number of Municipalities per Population (in Million) in 2013

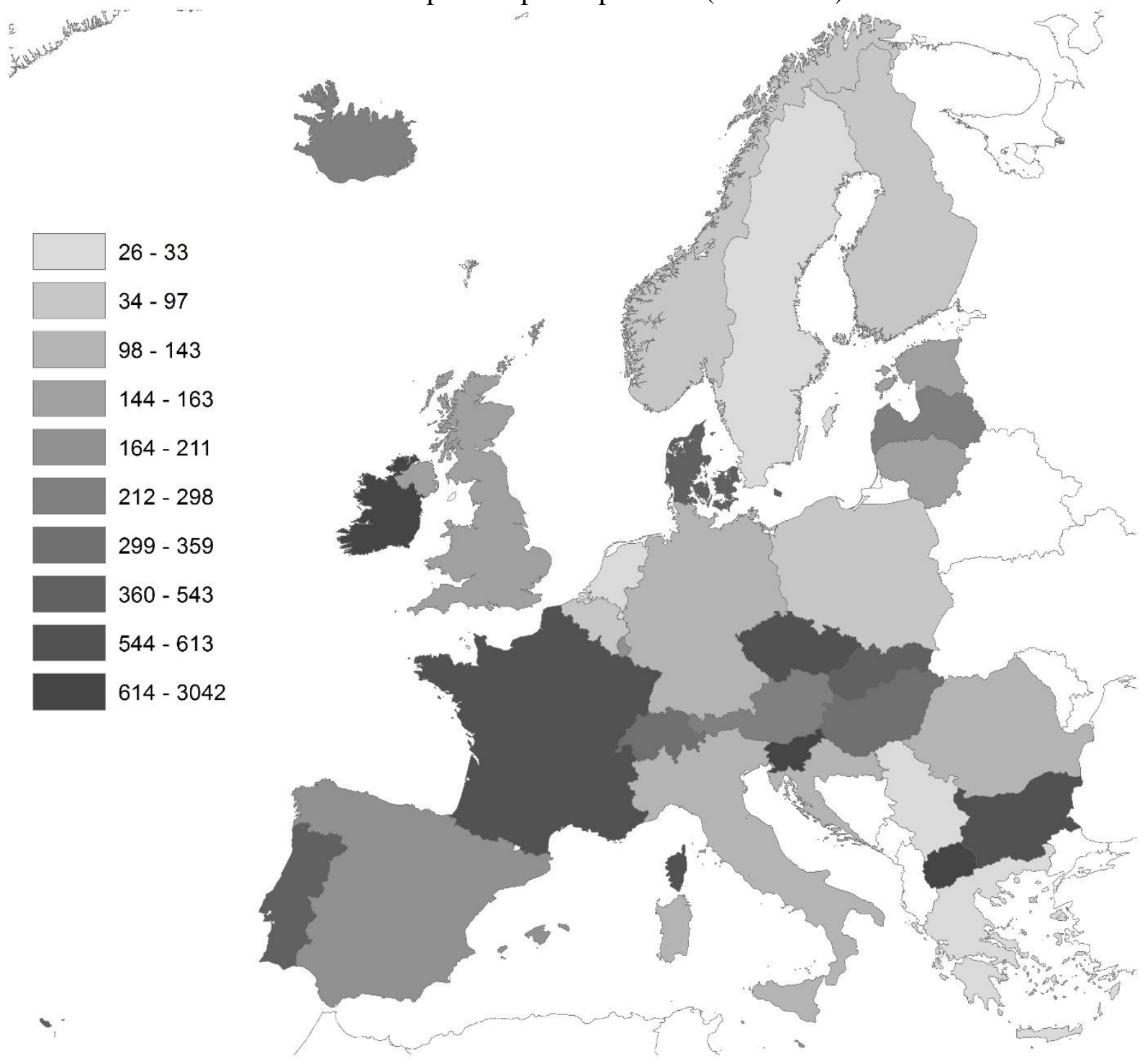

